\title{
Holocene sea level and environmental change at the southern Cape - an 8.5 kyr multi-proxy paleoclimate record from Lake Voëlvlei, South Africa
}

\author{
Paul Strobel $^{1}$, Marcel Bliedtner ${ }^{1}$, Andrew S. Carr ${ }^{2}$, Peter Frenzel ${ }^{3}$, Björn Klaes ${ }^{4}$, Gary Salazar ${ }^{5}$, Julian Struck ${ }^{1}$, \\ Sönke Szidat ${ }^{5}$, Roland Zech ${ }^{1}$, and Torsten Haberzettl ${ }^{6}$ \\ ${ }^{1}$ Physical Geography, Institute of Geography, Friedrich Schiller University Jena, Jena, Germany \\ ${ }^{2}$ School of Geography, Geology and the Environment, University of Leicester, Leicester, UK \\ ${ }^{3}$ Institute of Geosciences, Friedrich Schiller University Jena, Jena, Germany \\ ${ }^{4}$ Department of Geology, Trier University, Trier, Germany \\ ${ }^{5}$ Department of Chemistry, Biochemistry and Pharmaceutical Sciences and Oeschger Centre for Climate Change Research, \\ University of Bern, Bern, Switzerland \\ ${ }^{6}$ Physical Geography, Institute for Geography and Geology, University of Greifswald, Greifswald, Germany
}

Correspondence: Paul Strobel (paul.strobel@uni-jena.de)

Received: 28 September 2020 - Discussion started: 26 October 2020

Revised: 26 May 2021 - Accepted: 13 June 2021 - Published: 28 July 2021

\begin{abstract}
South Africa is a key region to reconstruct and understand past changes in atmospheric circulation, i.e. temperate westerlies and tropical easterlies. However, due to the scarcity of natural archives, South Africa's environmental evolution during the late Quaternary remains highly debated. Many available sediment archives are peri-coastal lakes and wetlands; however, the paleoenvironmental signals in these archives are often overprinted by sea-level changes during the Holocene. This study presents a new record from the coastal wetland Voëlvlei, which is situated in the year-round rainfall zone of South Africa on the southern Cape coast. It presents an ideal sedimentary archive to investigate both sea level and environmental changes. A $13 \mathrm{~m}$ long sediment core was retrieved and analysed using a multi-proxy approach. The chronology reveals a basal age of $8440+200 /-250$ cal BP. Paleoecological and elemental analyses indicate marine incursions from ca. 8440 to ca. 7000 cal BP with a salinity optimum occurring at $7090+170 /-200$ cal BP. At ca. $6000 \mathrm{cal} \mathrm{BP}$, the basin of Voëlvlei was in-filled with sediment resulting in an intermittent (sporadically desiccated) freshwater lake similar to present.

In contrast to previous investigations which used indirect proxies for hydrological reconstructions, here we apply a combined biomarker-sedimentological approach that allows the potential identification of precipitation sources, in com-
\end{abstract}

bination with relative estimates of moisture availability. Increasing moisture is observed throughout the record starting from $8440+200 /-250$ cal BP with contributions from both westerlies and easterlies from ca. 8440 to ca. $7070 \mathrm{cal} \mathrm{BP}$. Westerly-derived rainfall dominates from ca. 7070 to ca. 6420 cal BP followed by a distinct shift to an easterly dominance at ca. $6420 \mathrm{cal} \mathrm{BP}$. An overall trend to westerly dominance lasting until ca. $2060 \mathrm{cal}$ BP is followed by a trend towards an easterly dominance to the present, but both phases show several intense, short-term variations. These variations are also evident in other regional studies, highlighting that the source and seasonality of precipitation has varied distinctly on the southern Cape during the Holocene. Comparison of the Voëlvlei record with other regional studies suggests a coherent trend in the overall moisture evolution along the southern Cape coast during the past 8500 years.

\section{Introduction}

A record-breaking drought occurred in South Africa from 2015 to 2017, and future climate projections predict increasing drought for large parts of the country (Engelbrecht and Engelbrecht, 2016; Engelbrecht et al., 2011). To make climate models and predictions of future hydrological change 
more reliable, robust paleoclimate reconstructions using direct hydrological proxies are necessary but have been rare in South Africa up to now (Haberzettl et al., 2014). Southern Africa's past and present climate has been driven by complex interactions between two major oceanic and atmospheric circulation systems, i.e. the Benguela and Agulhas currents, and the westerlies and easterlies (Tyson and Preston-Whyte, 2000) (Fig. 1a). Today, three major rainfall zones occur in South Africa. While the eastern and central parts of the country receive most rainfall (> 66\%) from tropical moisture-bearing atmospheric circulation systems during austral summer (summer rainfall zone, SRZ), a narrow belt along the west coast receives most rainfall $(>66 \%)$ from temperate westerlies during the austral winter (winter rainfall zone, WRZ) (Fig. 1a). An intermediary area between the SRZ and WRZ receives rainfall from both systems throughout the year (year-round rainfall zone, YRZ) (Fig. 1a) (Engelbrecht et al., 2015; Scott and Lee-Thorp, 2004), and this includes the southern Cape coast, which is the focus area for this study.

The YRZ has been the focus of most paleoenvironmental and associated paleoclimatic research in this region. Here, the southern Cape coast, in particular the Wilderness area with its numerous coastal lakes including Bo Langvlei (du Plessis et al., 2020), Eilandvlei (Kirsten et al., 2018a, b; Quick et al., 2018; Reinwarth et al., 2013; Wündsch et al., 2018, 2016b), Groenvlei (Martin, 1959, 1968; Wündsch et al., 2016a) and Swartvlei (Birch et al., 1978; Haberzettl et al., 2019), has yielded multiple paleoenvironmental records (Fig. 1b). These coastal lakes have formed between large coastal dune cordons that lie parallel to the coast. However, the terrestrial climate signals in these coastal archives are often overprinted by marine water intrusions induced by relative sea level change during the Holocene (Martin, 1959, 1968; Reinwarth et al., 2013; Wündsch et al., 2018, 2016a) or anthropogenic impacts, e.g. farming, water abstraction and dredging operations (Haberzettl et al., 2019). Further paleoenvironmental information from this area is available from, for example, peatlands (Quick et al., 2016; Strobel et al., 2019), speleothems (Braun et al., 2018, 2020; Talma and Vogel, 1992), rock hyrax middens (Chase et al., 2019, 2020, 2017, 2018, 2015) and marine sediments (Hahn et al., 2017) (Fig. 1a). However, the climate evolution of South Africa is still debated, reflecting potential spatial variability in climate drivers at the regional scale, and the application of different methodological approaches in various studies (Chase and Quick, 2018; Strobel et al., 2019). Consequently, our understanding of environmental dynamics and changing interactions between tropical and temperate climate systems affecting the YRZ is limited.

Compound-specific stable isotope analyses of hydrogen and carbon isotopes of long-chain $n$-alkanes ( $\geq \mathrm{C}_{25}$; $\delta^{2} \mathrm{H}_{n \text {-alkane, }} \delta^{13} \mathrm{C}_{n \text {-alkane }}$ ) are valuable proxies that complement established methodological approaches related to paleoenvironmental and paleohydrological changes in sediment
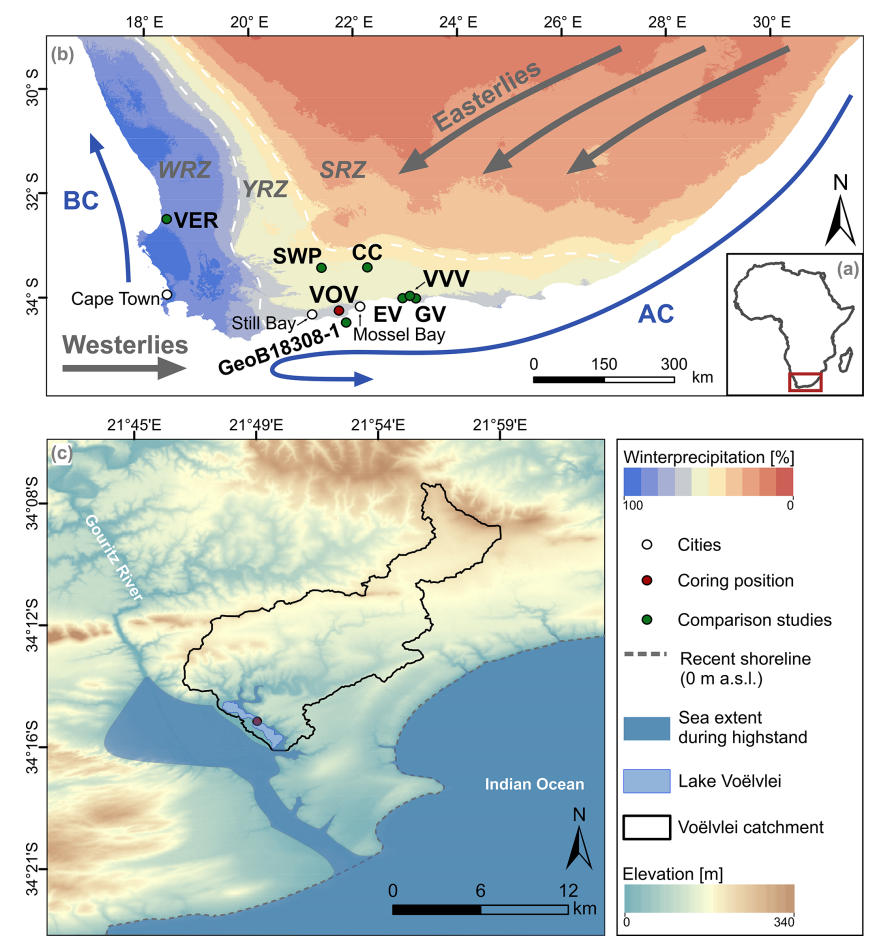

Figure 1. (a) Simplified map of Africa. The red box highlights the studied area. (b) Location of Lake Voëlvlei (VOV) and studies mentioned in the text (Cango Cave: CC, Talma and Vogel, 1992; Eilandvlei: EV, Quick et al., 2018; Wündsch et al., 2018; Groenvlei: GV, Wündsch et al., 2016a; Seweweekspoort: SWP, Chase et al., 2017; Verlorenvlei: VER, Kirsten et al., 2020; and Vankervelsvlei: VVV, Strobel et al., 2019). Additionally, the circumpolar westerlies, the tropical easterlies, the Agulhas Current (AC) and the Benguela Current (BC) are depicted. (c) Voëlvlei, its catchment, the coring position as well as a paleo-sea level highstand $(+5 \mathrm{~m})$ and the recent shoreline (data sources - rainfall seasonality: WorldClim 2 dataset, Fick and Hijmans, 2017; circulation systems after Chase and Meadows, 2007; DEM: SRTM 1 arcsec; 30 m, Jarvis et al., 2008).

archives, e.g. grain size analyses, geochemistry and palynology. Long-chain $n$-alkanes are leaf waxes produced by higher terrestrial plants and serve as valuable biomarkers as they remain well preserved in soils and sediments over millennia because of their low water solubility and high resistance to degradation (Eglinton and Eglinton, 2008; Sachse et al., 2012; Sessions, 2016). In South Africa, the $\delta^{2} \mathrm{H}_{n \text {-alkane }}$ signal shows potential to reconstruct the isotopic signal of precipitation and thus directly refers to the precipitation source (Herrmann et al., 2017; Strobel et al., 2020). However, $\delta^{2} \mathrm{H}_{n \text {-alkane }}$ has rarely been used in terrestrial archives at the southern Cape coast (Strobel et al., 2019).

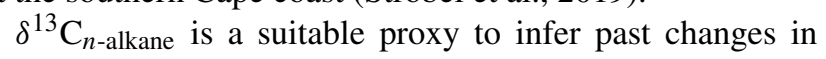
the vegetation composition (e.g. Diefendorf and Freimuth, 2017) as well as variations in plant water use efficiency and thus drought stress (Diefendorf and Freimuth, 2017; Struck et al., 2020). Therefore, using the climatic information from both leaf wax isotopes enables climate reconstructions based 
on the isotopic signal of precipitation, which can reflect local water availability. Further, leaf wax-derived $n$-alkanes can be used as a chronological marker since they can be dated using ${ }^{14} \mathrm{C}$ analyses (Bliedtner et al., 2020, 2018; Douglas et al., 2014; Gierga et al., 2016; Haas et al., 2017).

Here we present a sediment record from Voëlvlei, today an intermittent lake (sporadically desiccated), to reconstruct past sea level and environmental changes at the southern Cape coast of South Africa. A multi-proxy approach has been applied to the sediments, comprising compound-specific stable isotope analyses of leaf waxes as well as sedimentological assays of inorganic and organic elemental compositions, and paleoecological analyses on fossil remains. Specifically we aim to

i. establish a robust chronology based on diverse dating approaches on different sediment compounds,

ii. disentangle marine and climate influences during the development of Voëlvlei, and

iii. infer variations in local moisture availability and the source of precipitation.

\section{Site description}

Voëlvlei is situated ca. $40 \mathrm{~km}$ east of Still Bay and $30 \mathrm{~km}$ west of Mossel Bay, at an elevation of $5 \mathrm{~m}$ above present sea level (a.s.l.) ca. $10 \mathrm{~km}$ inland of the Indian Ocean coast. Today, Voëlvlei has an area of $3.8 \mathrm{~km}^{2}$ (max. length $4.2 \mathrm{~km}$; max. width $0.7 \mathrm{~km}$ ) and the catchment has an area of $165 \mathrm{~km}^{2}$ (database: SRTM 1 arcsec; Jarvis et al., 2008) (Fig. 1c). The catchment altitudes vary between 5 and $333 \mathrm{~m}$ a.s.l. (database: SRTM 1 arcsec; Jarvis et al., 2008) and is drained by one ephemeral river (Buffels River), which enters Voëlvlei to the north. A barrier elevated up to $17 \mathrm{~m}$ a.s.l. (database: SRTM 1 arcsec; Jarvis et al., 2008) defines the southern border of the Voëlvlei catchment. Voëlvlei has one intermittent outflow in the south-west at $6 \mathrm{~m}$ a.s.l. (SRTM 1 arcsec; Jarvis et al., 2008) and drains into the Gouritz river (Fig. 1c).

The geology is characterized by Palaeozoic quartzites of the Table Mountain Group (Cape Supergroup), mudrocksandstones of the Bokkeveld Group (Cape Supergroup), Mesozoic mudrock-sandstone conglomerates (Uitenhage Group) and Cenozoic limestone-sandstone conglomerates (Bredasdorp Group) (Johnson et al., 2006). Soils have high aluminium and iron concentrations and are mostly Cambisols and Leptosols (Fey, 2010; Zech et al., 2014).

The potential natural vegetation (i.e. that which would be expected to occur in the absence of human impact) consists of variations of fynbos, and only small areas along the main drainage system would be covered by Albany thicket (Mucina and Rutherford, 2006). Today, large areas of the catchment are used for agriculture. The steep slopes of the drainage system are mainly unmanaged and covered by plant communities of the fynbos and Albany thicket.
Mean annual precipitation at the study site is $450 \mathrm{~mm} \mathrm{yr}^{-1}$ (Fick and Hijmans, 2017), and rainfall is almost equally distributed throughout the year. Winter precipitation is linked to the temperate westerlies related to the Atlantic ocean as moisture source, and summer precipitation is associated with the tropical easterlies and the Indian Ocean as moisture source (Engelbrecht and Landman, 2016). Moreover, orographic rainfall occurs from local sources due to onshore flows related to ridging anticyclones (Weldon and Reason, 2014). The isotopic composition of precipitation $\left(\delta^{2} \mathrm{H}_{p}\right)$ is ${ }^{2} \mathrm{H}$-depleted during winter and ${ }^{2} \mathrm{H}$-enriched during summer periods, with a modelled annual mean of $-13 \pm 1 \%$ o (Table 1) (Bowen, 2018; Bowen et al., 2005; Braun et al., 2017; Harris et al., 2010). Mean annual temperature is $17.6^{\circ} \mathrm{C}$ and slightly higher temperatures during summer $\left(22^{\circ} \mathrm{C}\right)$ lead to semi-arid climatic conditions at the study site today (Fick and Hijmans, 2017).

\section{Material and methods}

For this study, the $13 \mathrm{~m}$ long sediment core (VOV16) was retrieved from Voëlvlei $\left(34.259^{\circ} \mathrm{S} ; 21.826^{\circ} \mathrm{E}\right.$; Fig. 1c) in 2016 using a percussion hammer coring system (inner core diameter $5 \mathrm{~cm}$ ) and transported to the Physical Geography laboratory of the Friedrich Schiller University Jena where it was stored under dark and cool (ca. $4^{\circ} \mathrm{C}$ ) conditions until processing. Cores were opened, cleaned and photo-documented, and their sedimentological properties and sediment colour were described in detail following the standard protocols of the Physical Geography laboratory at Friedrich Schiller University Jena.

\subsection{Chronology}

\subsubsection{Radiocarbon dating of macro particle, bulk TOC and $n$-alkane samples}

The chronology of the sediment record is based on ${ }^{14} \mathrm{C}$ ages from 1 organic plant-macro particle, 3 charcoal samples, 15 bulk organic samples and $7 n$-alkane samples (compoundclass). In total, 12 of the bulk organic samples and the organic plant-macro particle were analysed using accelerator mass spectrometry (AMS) at the Poznan Radiocarbon Laboratory, Poland. Three bulk organic, three charcoal and seven $n$-alkane samples (see Sect. 3.7 for sample extraction prior to measurement) were analysed with the Mini Carbon Dating System (MICADAS) AMS coupled to an element analyser (Ruff et al., 2010; Salazar et al., 2015; Szidat et al., 2014) at the LARA AMS Laboratory, University of Bern, Switzerland. ${ }^{14} \mathrm{C}$ results from the LARA AMS were reported as $\mathrm{F}^{14} \mathrm{C}$ and corrected for cross-contamination and constant contamination after Salazar et al. (2015). 
Table 1. Modelled isotopic hydrogen composition of precipitation at Voëlvlei (latitude: $34.013^{\circ} \mathrm{S}$; longitude: $22.904^{\circ} \mathrm{E}$; elevation: $5 \mathrm{~m}$ ) (Bowen, 2018; Bowen et al., 2005).

\begin{tabular}{lcccccccccccc}
\hline & January & February & March & April & May & June & July & August & September & October & November & December \\
\hline$\delta^{2} \mathrm{H}_{\mathrm{p}}$ [\%o vs. V-SMOW] & 6 & 4 & 3 & -12 & -21 & -26 & -29 & -33 & -23 & -16 & -12 & -4 \\
\hline
\end{tabular}

\subsubsection{OSL dating}

A split (half) section of the core was sub-sampled under red light conditions at the University of Leicester luminescence dating laboratory. The upper 5-6 $\mathrm{mm}$ of the sediment surface was removed, and the core section was sampled over a depth range of $70 \mathrm{~mm}$. Sediment within 6-7 $\mathrm{mm}$ of the core tube inner surface was not sampled but was used for an estimation of sample water content. This (dry) material as well as material from the upper surface was homogenized and used for dose rate analysis. The sediment for equivalent dose analysis was soaked in sodium hexametaphosphate and then wet sieved. The core sediments yielded very limited amounts of sandsized material, most of which was less than $100 \mu \mathrm{m}$. This necessitated the use of the fine sand range 55-90 $\mu \mathrm{m}$ for equivalent dose analysis. This material was prepared using standard methods (e.g. Aitken, 1985; Preusser et al., 2008; Wintle, 1997). This involved treatment with dilute (10\%) hydrochloric acid (to remove carbonates) and (32\%) hydrogen peroxide (to remove organics). The sample was then dried and density separated to isolate the $<2.7 \mathrm{~g} \mathrm{~cm}^{-3}$ and $>2.58 \mathrm{~g} \mathrm{~cm}^{-3}$ (quartz) fraction, before etching for $45 \mathrm{~min}$ in $48 \%$ hydrofluoric acid, washing in dilute hydrochloric acid (HF, to remove fluorides) and dry sieving $(55 \mu \mathrm{m})$. The HF etch removed any remaining $\mathrm{K}$ feldspars and also served to etch the (alpha irradiated) outer surface of the quartz grains.

Dose rates were determined using the same core material used to estimate water content via inductively coupled plasma mass spectrometry (ICP-MS) for U and Th and ICPOES for $\mathrm{K}$ analyses at the University of Leicester. The concentrations of $\mathrm{U}$, Th and $\mathrm{K}$ were converted to annual dose rates following Guérin et al. (2011) with corrections for grain size (Mejdahl, 1979), water content (Aitken, 1985) and HF etching (Bell, 1979). Cosmic dose rates were determined using the reported sample depth following Prescott and Hutton (1994) with a $5 \%$ relative uncertainty included. Final age uncertainties incorporate $3 \%$ relative uncertainties for the dose rate conversion factors, grain size attenuation factor, water attenuation and $\mathrm{HF}$ etching, propagated in quadrature. HF etching is assumed to have entirely removed the $\alpha$-irradiated outer portion of the quartz grains. It was assumed that the as-measured water content was appropriate with a $3 \%$ (absolute content) uncertainty propagated to the final dose rate uncertainty. In the absence of robust direct evidence for a substantially different water content in the past, we have utilized the modern sample water content. The $3 \%$ absolute uncertainty associated with this will account for some fluctuations through time. For reference, a $10 \%$ (absolute) change in water content results in an age difference of approximately 700 years.

All luminescence measurements were performed on a Ris $\varnothing$ DA20 TL/OSL reader. Stimulation $\left(40 \mathrm{~s}\right.$ at $\left.125^{\circ} \mathrm{C}\right)$ was provided by blue LEDs (stimulation wavelength $470 \mathrm{~nm}$ ) with OSL signals detected with an EMI 9235QA photomultiplier tube via a U-340 detection filter. Laboratory irradiations were delivered by a ${ }^{90} \mathrm{Sr}$ beta source with a dose rate (at the time of measurement) of ca. $7.58 \mathrm{~Gy} \mathrm{~min}^{-1}$. Sample equivalent doses $\left(D_{e}\right)$ were determined using the singlealiquot regeneration (SAR) protocol (Murray and Wintle, 2000, 2003; Wintle and Murray, 2006). All single-aliquot measurements were carried out on small ( 1 to $2 \mathrm{~mm}$ ) aliquots, which given the grain size fraction analysed means there are likely > 1000 grains per aliquot (e.g. Duller, 2008).

A dose recovery preheat experiment was used to assess the suitability of the SAR protocol in general, and the most appropriate preheating conditions. The overall dose recovery ratio across all preheating temperatures $\left(160-260^{\circ} \mathrm{C}\right)$ was $0.97 \pm 0.03$ ( $n=22$; zero overdispersion), with a ratio of $1.00 \pm 0.02(n=3)$ for the chosen preheat temperature combination of $240^{\circ} \mathrm{C}$ for $10 \mathrm{~s}$ (natural regeneration points) and a $220^{\circ} \mathrm{C}$ cut heat for the test dose measurements. All SAR analyses comprised a 7-regeneration point sequence, which included a repeated (recycling) regeneration dose point, an IR depletion regeneration dose point to check for $\mathrm{K}$ feldspar contamination (Duller, 2003) and a zero-dose point. The 4 (unique) point dose response curve was generated using the initial $0.64 \mathrm{~s}$ of stimulation, with a background signal from the last $8 \mathrm{~s}$. Analyses were carried out in the "Analyst" software. Dose response curves were fitted with saturating exponential fits, with $\mathrm{D}_{\mathrm{e}}$ uncertainties incorporating counting statistics, curve fitting uncertainties and a $1 \%$ systematic uncertainty (Duller, 2007) (all calculated within the Ris $\varnothing$ Analyst software). The uncertainty in the final $\mathrm{D}_{\mathrm{e}}$ estimate also incorporates an additional beta source calibration uncertainty $(3 \%)$.

\subsubsection{Age modelling}

For the final age-depth modelling, all aforementioned dates were used. Bulk organic and $n$-alkane ${ }^{14} \mathrm{C}$ ages from the terrestrial part of the sediment core were calibrated with the SHcal20 data calibration curve (Hogg et al., 2020), whereas ${ }^{14} \mathrm{C}$ ages from the marine part of the record were calibrated with the Marine20 calibration curve (Heaton et al., 2020) and additionally corrected for a marine reservoir effect using a $\Delta \mathrm{R}$ of $134 \pm 38^{14} \mathrm{C}$ years as previously reported by Wünd- 
sch et al. (2016b) (Table 1). For the compound-class $n$-alkane samples, the SHCal20 calibration curve (Hogg et al., 2020) was applied due to a predominance of terrestrial synthesized long-chain $n$-alkanes $\left(\mathrm{C}_{29}, \mathrm{C}_{31}, \mathrm{C}_{33}\right)$ in the samples (see Sect. 4.3; Table 1). The terrestrial organic plant-macro particle and charcoal found in the marine part of the record were calibrated with the SHCal20 curve (Hogg et al., 2020) (Table 1). All calibrations were done with the online version of the Calib 8.2 software (Stuiver et al., 2020). The final agedepth profile was modelled with the $\mathrm{R}$ software package $\mathrm{Ba}-$ con 2.4.3 (Blaauw and Christen, 2011), using the same calibration datasets. In the following, ages are reported as median ages including the upper and lower limit of the $95 \%$ confidence interval.

\subsection{Grain size analyses}

For grain size measurement $50 \mathrm{mg}$ sample aliquots were treated with $\mathrm{H}_{2} \mathrm{O}_{2}(10 \%)$ to remove organic matter, $\mathrm{HCl}(10 \%)$ for the destruction of carbonates and $\mathrm{Na}_{4} \mathrm{P}_{2} \mathrm{O}_{7} / \mathrm{Na}_{2} \mathrm{CO}_{3}$ for dispersion. The grain size distribution of each sample was determined with a Laser Particle Sizer (FRITSCH ANALYSETTE 22 Microtec, FRITSCH, Germany) and a wet dispersion unit at the Physical Geography laboratory of the University of Greifswald. Before the measurement, samples were treated with ultrasound for $60 \mathrm{~s}$ and subsequently measured in duplicate. The grain size distribution is calculated in 99 classes between $0.08-2000 \mu \mathrm{m}$. The mean and median grain size as well as fractions of clay, silt and sand of each sample were calculated.

\subsection{Paleontological analyses}

A selection of 23 sediment samples representing all lithological units and focusing on the assumed transition from an estuarine to a freshwater environment were processed and analysed micropaleontologically. About 3-7 mL of sediment from $1 \mathrm{~cm}$ thick sediment slices of the core was washed with tap water through stacked sieves of 63 and $200 \mu \mathrm{m}$ mesh size. After drying the sieve residues on a heating plate at ca. $50^{\circ} \mathrm{C}$, all microfossils were picked under a low-power stereomicroscope and transferred to microfossil slides for later identification and counting. Microfossils, fragments of macrofossils and charcoal were documented semi-quantitatively as rare (1-2 specimens), common $(>2)$, abundant $(>10)$ and very abundant $(>100)$. Identification relies on Benson and Maddocks (1964), Martens et al. (1996), and Fürstenberg et al. (2017) for Ostracoda and on Schmitt-Sinns (2008) and Fürstenberg et al. (2017) for Foraminifera. Additional macrofossils found during the lithological description, sampling of the core and processing the microfossils were identified, counted and used for paleoecological interpretation. These were all snails with identification relying mainly on Branch et al. (2010) and the mollusc section of the World Register of Marine Species (http://www.marinespecies.org/, last access:
8 July 2020). Bivalves could not be identified because they occurred only as fragments. Paleoecological information was drawn from the papers listed above for identification plus Murray (2006) and Kirsten et al. (2018a). All paleontological material will be stored at the South African Museum of Natural History in Cape Town.

\subsection{Elemental analyses}

$\mathrm{XRF}$ data $(\mathrm{Al}, \mathrm{Br}, \mathrm{Zr}$ ) were collected every $1 \mathrm{~cm}$ downcore using two generator settings $(30 \mathrm{kV}, 1 \mathrm{~mA}, 15 \mathrm{~s} ; 15 \mathrm{kV}$, $0.2 \mathrm{~mA}, 15 \mathrm{~s}$ ) for detection of different elemental groups with the XRF Core Scanner II (AVAATECH Serial No. 2) at MARUM at the University of Bremen. The split core surface was covered with a $4 \mu \mathrm{m}$ thin SPEXCerti Prep Ultralene1 foil to avoid contamination of the XRF measurement unit and desiccation of the sediment. The data reported here were acquired by a Canberra X-PIPS Silicon Drift Detector (SDD; Model SXD 15C-150-500) with $150 \mathrm{eV}$ X-ray resolution, the Canberra Digital Spectrum Analyzer DAS 1000 and an Oxford Instruments $50 \mathrm{~W}$ XTF5011 X-Ray tube with rhodium (Rh) target material. Raw data spectra were processed by the analysis of X-ray spectra by iterative least square software (WIN AXIL) package from Canberra Eurisys. The data were normalized by elemental $\mathrm{Zr}$ counts, i.e. $\mathrm{Al} / \mathrm{Zr}$ and $\mathrm{Br} / \mathrm{Zr}$, and plotted as log ratios, primarily to eliminate sediment matrix errors (water content, surface roughness and grain size variations) (Weltje and Tjallingii, 2008).

Moreover, 150 sample aliquots at $8 \mathrm{~cm}$ intervals were freeze dried $\left(-53{ }^{\circ} \mathrm{C}\right.$, for $\left.>48 \mathrm{~h}\right)$, ground and sieved to a size $<40 \mu \mathrm{m}$. Aluminium ( $\mathrm{Al}$ ), calcium (Ca) and sodium (Na) concentrations were measured with an ICP-OES 725ES (VARIAN, USA) at the Physical Geography laboratory of the Friedrich Schiller University Jena. A total of $0.2 \mathrm{~g}$ of the samples was processed using a microwave-assisted modified aqua regia digestion of $2 \mathrm{~mL} \mathrm{HCl}(32 \%)$ and $4 \mathrm{~mL} \mathrm{HNO}_{3}$ $(65 \%)$. Error estimates were based on triple measurements of three samples (VOV_243, VOV_651, VOV_1186; numbers indicate sample depth) (relative error: Al 3.7\%; Ca: $5.4 \%$; Na: $5.3 \%$ ). Samples of the reference material LGC6 187 (river sediment) were measured as well to calculate the relative analytical error which was $1.1 \%$ for $\mathrm{Al}$ and $\mathrm{Ca}$, and $10 \%$ for $\mathrm{Na}$.

Total nitrogen (TN) and total carbon (TC) were analysed with a CNS analyser (EuroVector EA 3000, HEKAtech $\mathrm{GmbH}$, Germany) at the Physical Geography laboratory of the University of Greifswald. Concentrations of total organic carbon (TOC) were determined with the same device after treatment with $3 \%$ and $20 \% \mathrm{HCl}$ at $80^{\circ} \mathrm{C}$ to remove carbonates. Error estimates were based on triple measurements of 30 samples (mean relative error: N: $8.9 \%$; TOC: $2.9 \%$ ). Total inorganic carbon (TIC) was calculated as difference between TC $[\%]$ and TOC [\%]. 


\subsection{Biogenic silica (BiSi)}

Biogenic silica (BiSi) concentrations were determined following Ohlendorf and Sturm (2008). BiSi and Al concentrations were measured using an ICP-OES 725-ES (VARIAN, USA) at the Physical Geography laboratory of the Friedrich Schiller University Jena. A correction factor of one (BiSi : Al; $1: 1$ ) was applied to account for dissolving aluminosilicates.

\subsection{Powder X-ray diffraction (XRD)}

The identification of the mineral composition of 50 powdered samples (e.g. Pecharsky and Zavalij, 2009) from representative core sections was carried out using an X-ray diffractometer (D8-Discover, Bruker AXS) equipped with a $\mathrm{CuK} \alpha \mathrm{X}$-ray tube and a gas proportional counter (HI-STAR area detector, Bruker AXS) at Friedrich Schiller University Jena. The qualitative analyses and interpretation of the diffractograms was conducted at Trier University using Bruker DIFFRAC plus 5.0 software. The occurrence of specific mineral phases (low, medium, high) was roughly estimated based on XRD peak intensities in conjunction with the elaborated geochemistry of the investigated sediment sections. For all measurements the quartz peak at $3.342 \AA$ was accepted as internal standard.

\subsection{Biomarker analyses of $n$-alkane distributions and stable isotope compositions}

Total lipids of the sediment samples (14.5-31.4 g) were extracted with $40 \mathrm{~mL}$ dichloromethane (DCM) and methanol $(\mathrm{MeOH})(9 / 1, v / v)$ using an ultrasonic bath over three $15 \mathrm{~min}$ cycles. The total lipid extract was separated by solid phase extraction using aminopropyl silica gel (Supelco, $45 \mu \mathrm{m})$ as the stationary phase. The $n$-alkanes were eluted with $4 \mathrm{~mL}$ hexane and further purified over coupled silvernitrate $\left(\mathrm{AgNO}_{3-}\right)$ - zeolite (Geokleen) pipette columns. The $n$-alkanes trapped in the zeolite were subsequently dissolved in HF and recovered by liquid-liquid extraction using $n$-hexane. An Agilent 7890 gas chromatograph equipped with an Agilent HP5MS column ( $30 \mathrm{~m}, 320 \mu \mathrm{m}, 0.25 \mu \mathrm{m}$ film thickness) and a flame ionization detector (GC-FID) was used for identification and quantification of the $n$-alkanes, relative to external $n$-alkane standards ( $n$-alkane mix $n$ - $\mathrm{C}_{21}$ $n$ - $\mathrm{C}_{40}$, Supelco).

$n$-Alkane concentrations were calculated as the sum of $\mathrm{C}_{25}$ to $\mathrm{C}_{35}$ and are given in $\mu \mathrm{gg}^{-1}$ dry weight. Odd-overeven predominance (OEP) values (Eq. 1) were determined following Hoefs et al. (2002). Low values $(<5)$ indicate an enhanced state of degradation (Buggle et al., 2010; Zech et al., 2010). The average chain length (ACL) (Eq. 2) was calculated from the odd-numbered $n$-alkanes (Poynter et al., 1989).

$$
\begin{aligned}
\mathrm{OEP} & =\left(\frac{n \mathrm{C}_{27}+n \mathrm{C}_{29}+n \mathrm{C}_{31}+n \mathrm{C}_{33}}{n \mathrm{C}_{26}+n \mathrm{C}_{28}+n \mathrm{C}_{30}+n \mathrm{C}_{32}}\right) \\
\mathrm{ACL} & =\frac{27 \cdot n \mathrm{C}_{27}+29 \cdot n \mathrm{C}_{29}+31 \cdot n \mathrm{C}_{31}+33 \cdot n \mathrm{C}_{33}}{n \mathrm{C}_{27}+n \mathrm{C}_{29}+n \mathrm{C}_{31}+n \mathrm{C}_{33}}
\end{aligned}
$$

Compound-specific stable hydrogen isotope analyses of the $\mathrm{C}_{31}$ and $\mathrm{C}_{33} n$-alkanes were carried out on an IsoPrime vision IRMS, coupled to an Agilent 7890A GC via a GC5 pyrolysis or combustion interface operating in pyrolysis modus with a MaxChrome and silver wool packed reactor at $1050^{\circ} \mathrm{C}$. Samples were injected with a split-splitless injector. The GC was equipped with $30 \mathrm{~m}$ fused silica column (HP5-MS, $0.32 \mathrm{~mm}, 0.25 \mu \mathrm{m}$ ). Each sample was analysed in triplicate, except for single measurements of three samples (VOV_915, VOV_128, VOV_111; numbers indicate sediment depth) due to insufficient compound abundance. $\delta^{2} \mathrm{H}_{n \text {-alkane }}$ was measured against calibrated $\mathrm{H}_{2}$ reference gas and all values are reported in \%o against VSMOW. The precision was checked by co-analysing a standard alkane mixture ( $\left.n-\mathrm{C}_{27}, n-\mathrm{C}_{29}, n-\mathrm{C}_{33}\right)$ with known isotope composition (Arndt Schimmelmann, University of Indiana), injected in duplicate every nine runs. All measurements were corrected for drift and amount dependency, relative to the standard values in each sequence. Triplicates for the $\mathrm{C}_{31}$ and $\mathrm{C}_{33}$ alkanes had a standard deviation of $<4.0 \%$; the analytical error for the standards was $<1.7 \%$ o $(n=68)$. The $\mathrm{H}_{3}^{+}$factor was checked every $2 \mathrm{~d}$ and stayed stable at $4.40 \pm 0.03$ during measurements.

Compound-specific stable carbon isotope analyses of $\mathrm{C}_{31}$ and $\mathrm{C}_{33} n$-alkanes were carried out on an IsoPrime vision IRMS, coupled to an Agilent 7890A GC via a GC5 pyrolysis or combustion interface operating in combustion modus with a $\mathrm{CuO}$ and silver wool packed reactor at $850^{\circ} \mathrm{C}$. Samples were injected with a split-splitless injector. The GC was equipped with $30 \mathrm{~m}$ fused silica column (HP5-MS, $0.32 \mathrm{~mm}$, $0.25 \mu \mathrm{m}) . \delta^{13} \mathrm{C}_{n \text {-alkane }}$ values were calibrated against $\mathrm{CO}_{2}$ reference gas of known isotopic composition and all carbon isotope values are given in \%o against VPDB. Triplicate injections were conducted for each sample and measurement accuracy was controlled in the same way as for the $\delta^{2} \mathrm{H}_{n \text {-alkane }}$ analyses. Triplicates for the $\mathrm{C}_{31}$ and $\mathrm{C}_{33}$ alkanes had a standard deviation of $<0.2 \%$; the analytical error for the standards was $<0.2 \%$ o $(n=83)$.

\section{Results}

\subsection{Lithology and chronology}

The sediment sequence is $13 \mathrm{~m}$ long and consists of three lithological units defined by differences in sediment colour and grain size (Fig. 2). Unit A from 13 to $4.51 \mathrm{~m}$ depth consists of dark greyish material and is dominated by silt. Within this unit, several thin greyish clayey and yellowish sandy layers are present. Unit B from 4.51 to $0.78 \mathrm{~m}$ sediment 
depth consists of brownish to reddish silty material. In the lower parts of Unit B thin greyish clayey layers are observed. Unit $C$ from $0.78 \mathrm{~m}$ sediment depth to the top is dominated by dark brown silty material. Moreover, two layers (0.53-0.44; $0.31-0 \mathrm{~m}$ sediment depth) can be separated through changes in colour and granulometric structure in Unit C (Fig. 2).

The chronology reveals a basal age of $8440+200 /-250$ cal BP (Fig. 2, Table 2) and considering a $95 \%$ confidence interval $76 \%$ of the ages overlap with the age-depth model. In Unit $\mathrm{A},{ }^{14} \mathrm{C}$ ages from the bulk samples are stratigraphically consistent, except for two samples at 11.19 and $5.66 \mathrm{~m}$ sediment depth, which are too young for their stratigraphic position. The ${ }^{14} \mathrm{C}$ age ranges of a terrestrial organic plant-macro particle and a reservoir-corrected bulk sediment sample at 9.63 and $9.61 \mathrm{~m}$ overlap. At $4.57 \mathrm{~m}$ sediment depth, two charcoal samples and a reservoir-corrected bulk sediment sample distinctly overlap as well. Above the bulk sediment sample at $4.57 \mathrm{~m}$ sediment depth, four bulk sediment samples are too old for their stratigraphic position and are not in stratigraphic order (Units B and C). In contrast, ${ }^{14} \mathrm{C}$ ages obtained from the $n$-alkane samples are distinctly younger and are in stratigraphic order in Units B and C (Table 2; Fig. 2).

Consistent with the good dose recovery results the OSL sample produced a bright, rapidly decaying quartz OSL signal (reduced to ca. $2 \%$ of the initial signal within $1 \mathrm{~s}$ ). None of the analysed aliquots exhibited recycling ratios or IR ratios beyond/below (respectively) $10 \%$ of unity or recuperation (zero dose signal) $>1 \%$ of the natural signal. The equivalent dose distribution however is overdispersed (40 $\pm 5 \%$; Table 3), even after removal of one very high ( $125 \mathrm{~Gy}$ ) outlier, and despite the considerable signal averaging that is likely given the use of the fine sand fraction for analysis. In the context of the analysed core, its likely antiquity, and the otherwise excellent performance of the sample implied by the dose recovery experiment and internal checks within the SAR protocol, a parsimonious explanation of this broad distribution is the presence of unbleached or incompletely bleached grains. Indeed, the age obtained from the central age model equivalent dose estimate is $10 \pm 1 \mathrm{ka}$, which is implausible given the stratigraphic position of the sample (Fig. 2). Application of a three-component minimum age model (MAM) (Galbraith et al., 1999) administered in the R package "Luminescence" (Burrow, 2019) produces a $D_{e}$ estimate of $20.3 \pm 2.4 \mathrm{~Gy}$ and an age of $6.8 \pm 0.8 \mathrm{ka}$ (Table 3). While caution is required when applying this approach to multi-grain aliquots (especially those with considerable signal averaging as here), the minimum age estimate is much more concordant with the radiocarbon ages from this section of the core and the broader age-depth model for the whole sequence (Fig. 2). In addition, the MAM-derived OSL age is in stratigraphic order with the ${ }^{14} \mathrm{C}$ ages derived from the $n$-alkane and charcoal samples (Fig. 2).

\subsection{Geochemical and paleontological analyses}

Significant correlations (Pearson's $r ; \alpha<0.05$ ) were obtained for the log-normalized XRF scanning data for $\mathrm{Br} / \mathrm{Zr}$ and $\mathrm{Al} / \mathrm{Zr}$ compared to the quantitative elemental contents of $\mathrm{Na}$ and $\mathrm{Al}$, respectively $(r: \log (\mathrm{Br} / \mathrm{Zr}) / \mathrm{Na}=0.82 ; r$ : $\log (\mathrm{Al} / \mathrm{Zr}) / \mathrm{Al}=0.71$; Fig. 3). $\mathrm{Na}$ concentrations range from $2090 \pm 110$ to $10390 \pm 550 \mathrm{ppm}$ over the sequence. Both $\mathrm{Na}$ contents and $\mathrm{Br} / \mathrm{Zr}$ ratios show highest values in Unit $\mathrm{A}$ (13-4.51 m sediment depth). Several minima in the Br/Zr ratios derived from XRF-scanning data are not visible in the $\mathrm{Na}$ concentrations due to the higher sample resolution of the $\mathrm{XRF}$ data (Fig. 3). Both $\mathrm{Na}$ concentration and $\mathrm{Br} / \mathrm{Zr}$ ratios distinctly decrease above $4.51 \mathrm{~m}$ sediment depth, but an increase is noticeable in Unit $\mathrm{C}(<0.78 \mathrm{~m}$ sediment depth) (Fig. 3). Al concentrations range from $39300 \pm 1500$ to $82900 \pm 3100 \mathrm{ppm}$, and both $\mathrm{Al}$ contents and $\mathrm{Al} / \mathrm{Zr}$ ratios show high values over large parts of the sediment record. As mentioned previously, $\mathrm{Al} / \mathrm{Zr}$ ratios show minima in Unit $\mathrm{A}$, which are not visible in the Al concentrations due to the higher sample resolution of the XRF-scanning data (Fig. 3). Noticeable are distinct low concentrations of $\mathrm{Al}$ and $\mathrm{Al} / \mathrm{Zr}$ ratios from 4.51 to $2.91 \mathrm{~m}$ sediment depth and at $1.82 \mathrm{~m}$ sediment depth, with an increasing trend to the top of the record (Fig. 3).

TOC and $\mathrm{N}$ range from $0.16 \%$ to $3.94 \%$ and $0.03 \%$ to $0.48 \%$ respectively; they show high values in the lower parts of the core $(>4.51 \mathrm{~m}$ sediment depth) and distinctly decrease above $4.51 \mathrm{~m}$ sediment depth and increase thereafter again (Fig. 3). The $\mathrm{C} / \mathrm{N}$ molar ratio ranges between 1.9 and 13.6 over the whole sequence with high values between 5.15 and $4.27 \mathrm{~m}$ sediment depth (Fig. 3). TIC ranges from $0 \%$ to $0.86 \%$ with noticeable peaks between 6.91 and 6.51 , and at 4.83, 2.59 and $1.74 \mathrm{~m}$ sediment depth (Fig. 3). Ca concentrations show a similar pattern to TIC and range from $2830 \pm 150$ to $28900 \pm 1600 \mathrm{ppm}$ (Fig. 3). BiSi concentrations range from $0.8 \pm 0.02 \%$ to $2.8 \pm 0.08 \%$ with low values in the lower parts of the record ( $>6.99 \mathrm{~m}$ sediment depth), except for high values between 10.98 and $10.10 \mathrm{~m}$ sediment depth $(1.6 \pm 0.05 \%$ to $2.2 \pm 0.07 \%$ ) (Fig. 3$)$. They show high values for the upper part of the record $<6.91 \mathrm{~m}$ sediment depth (Fig. 3).

Apart from the selected mineral components of the XRD measurements displayed in Fig. 3, all samples have a predominance of quartz, feldspars and micas. Calcite follows the patterns of TIC and $\mathrm{Ca}$ and shows highest abundances between 11.46 and 10.18 as well as 3.87 and $2.19 \mathrm{~m}$ sediment depth (Fig. 3). The other sections have only medium to low proportions of calcite (Fig. 3). The presence of gypsum is restricted to depths between 9.62 and $9.14 \mathrm{~m}$ as well as 5.47 and $5.23 \mathrm{~m}$ (Fig. 3). However, an absence of calcite and/or gypsum at the distinct peaks of TIC and Ca (e.g. 2.59 and $1.74 \mathrm{~m}$ sediment depth) is likely due to the lower sample resolution of the XRD measurements compared to the elemental data (Fig. 3). High proportions of halite are present in 


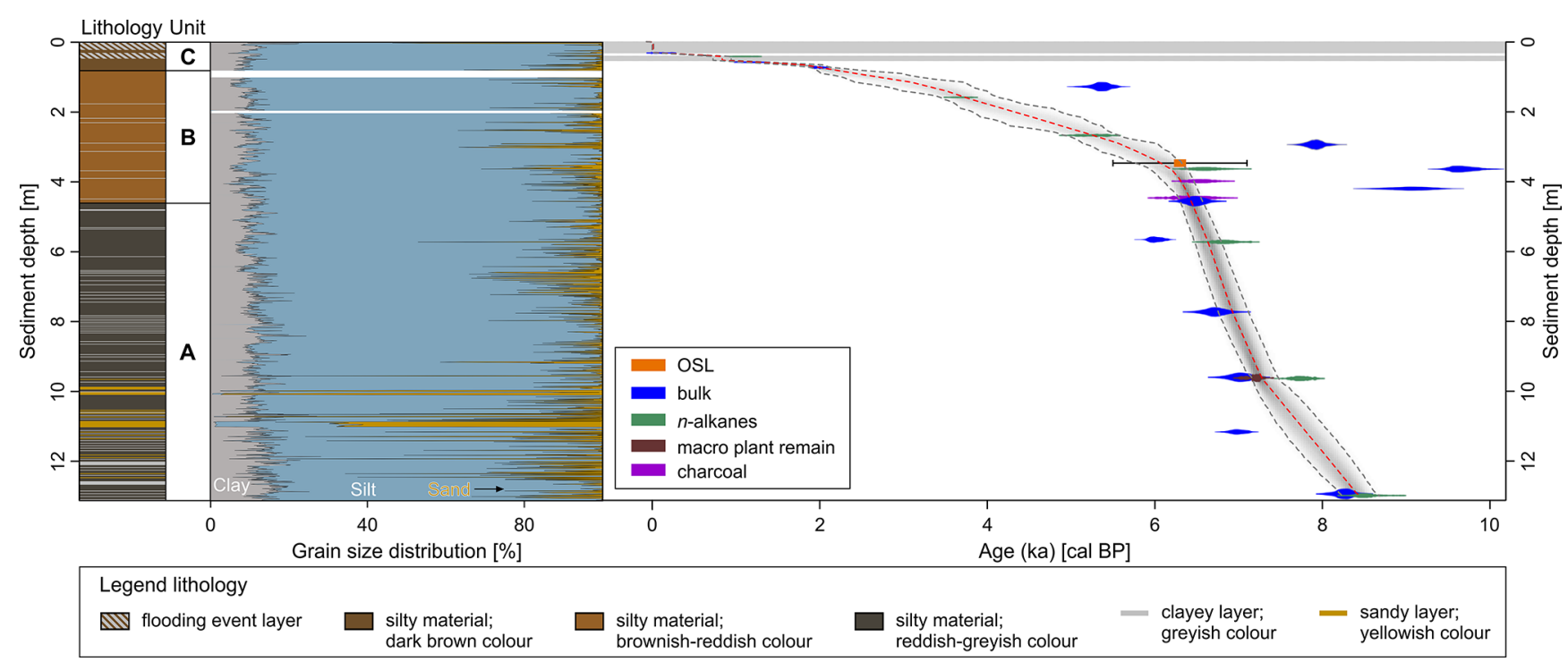

Figure 2. Left: lithology and grain size distribution (clay, silt, sand) of the VOV16 record from Voëlvlei. Right: age-depth model of the sediment record from Voëlvlei. Calibrated radiocarbon ages are displayed as probability density functions of the $2 \sigma$ distributions (blue: bulk sediment; green: compound-class n-alkane samples; brown: macro plant remain). Calibration and age-depth modelling was carried out using the R software package Bacon 2.4.3 (Blaauw and Christen, 2011).

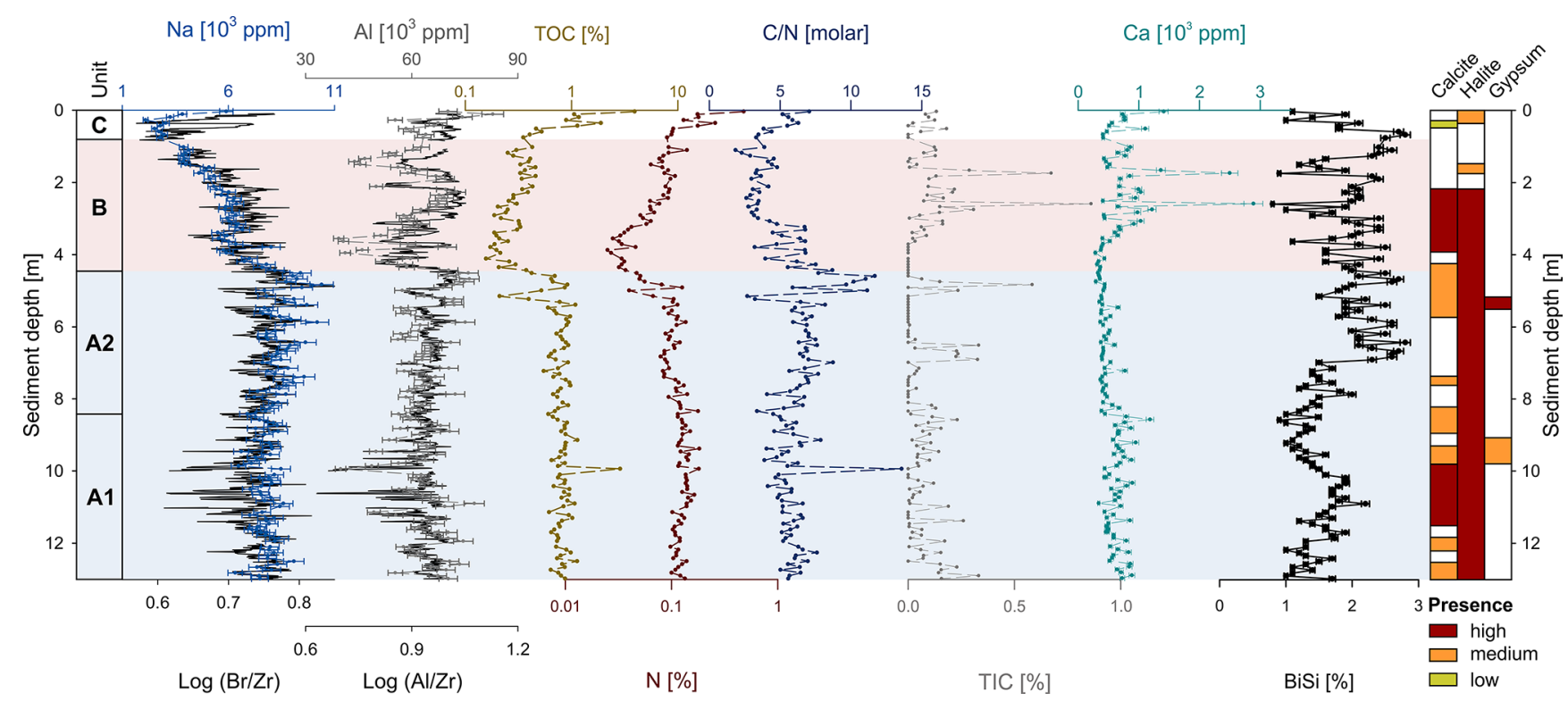

Figure 3. Lithological units, sodium (Na) content and $\log _{10}$ ratio of bromine (Br) and zirconium ( $\mathrm{Zr}$ ), aluminium ( $\mathrm{Al}$ ) and $\mathrm{Log} 10 \mathrm{ratio}$ of $\mathrm{Al}$ and $\mathrm{Zr}$, contents of total organic carbon (TOC), total nitrogen $(\mathrm{N})$, molar $\mathrm{C} / \mathrm{N}$ ratio, total inorganic carbon (TIC), calcium (Ca), and biogenic silica (BiSi) derived from the sediment core VOV16 from Voëlvlei. The presence of selected mineral components is also depicted.

large parts of the sediment record ( $>2.19 \mathrm{~m}$ sediment depth; Fig. 3).

$n$-Alkane concentrations range from 0.22 to $5.23 \mu \mathrm{gg}^{-1}$ with high values in Unit A and distinctly lower concentrations in Unit B and C (Fig. 4). All samples show a distinct odd-over-even predominance (4.0-15.5), and the ACL ranges from 29.9 to 31.4. Consequently, $\mathrm{C}_{29}, \mathrm{C}_{31}$ and $\mathrm{C}_{33}$ are the predominant $n$-alkane chain-lengths in all samples
(Fig. 4). $\delta^{13} C_{n \text {-alkane values range from }-28.10 \pm 0.16 \% o}$ to $-22.72 \pm 0.06 \%$ with more negative values at the bottom of Unit A (13.0-12.58 m composite depth), followed by less negative values (12.58-8.85 m composite depth), which show a decreasing trend upwards (Fig. 4). Notably are three

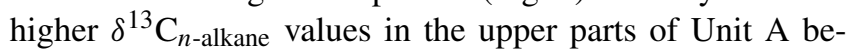
tween 6.35 and $4.51 \mathrm{~m}$ sediment depth (Fig. 4). $\delta^{2} \mathrm{H}_{n \text {-alkane }}$ values range from $-154.4 \pm 1.3 \%$ to $-129.6 \pm 1.1 \%$ with 
Table 2. Conventional radiocarbon ages as well as $2 \sigma$ calibrated age ranges and median calibrated ages (Calib 8.2) (Stuiver et al., 2020) using the SHCal20 and Marine20 calibration curve (Heaton et al., 2020; Hogg et al., 2020) of dated bulk sediment, $n$-alkanes and organic macro particle (OMP) samples from the VOV16 record. Samples from the marine and brackish parts of the record were reservoir corrected using a $\Delta \mathrm{R}$ of $134 \pm 38^{14} \mathrm{C}$ years after Wündsch et al. (2016b). 1: SHCal20; 2 : Marine20 and reservoir corrected using a $\Delta \mathrm{R}$ of $134 \pm 38{ }^{14} \mathrm{C}$ years after Wündsch et al. (2016b).

\begin{tabular}{|c|c|c|c|c|c|}
\hline $\begin{array}{l}\text { Sediment depth } \\
\text { depth }[\mathrm{m}]\end{array}$ & Lab ID & $\begin{array}{r}1 \sigma \text { conventional } \\
{ }^{14} \mathrm{C} \text { age }[\mathrm{BP}]\end{array}$ & $\begin{array}{l}\text { Dated } \\
\text { material }\end{array}$ & $\begin{array}{r}\text { Median cal age and } \\
2 \sigma \text { error } \\
{[\text { cal BP }]}\end{array}$ & Calibration \\
\hline 0.29 & Poz-94013 & $660 \pm 30$ & bulk & $610^{+75 /-25}$ & 1 \\
\hline 0.32 & BE-9770.1.1 & $-85 \pm 120$ & bulk & $100^{+85 /-85}$ & 1 \\
\hline 0.44 & BE-12027.1.1 & $1250 \pm 140$ & $n$-alkanes & $1110+250 /-130$ & 1 \\
\hline 0.51 & BE-9772.1.1 & $1855 \pm 120$ & bulk & $1740+270 /-270$ & 1 \\
\hline 0.59 & BE-9772.1.1 & $1360 \pm 120$ & bulk & $1210^{+470} /-250$ & 1 \\
\hline 0.75 & Poz-96323 & $2080 \pm 35$ & bulk & $2000+170 /-80$ & 1 \\
\hline 1.29 & Poz-94014 & $5330 \pm 50$ & bulk & $5370+410 /-210$ & $2^{\mathrm{a}}$ \\
\hline 1.59 & BE-12026.1.1 & $3470 \pm 90$ & $n$-alkanes & $3690+455 /-240$ & 1 \\
\hline 2.68 & BE-12025.1.1 & $4630 \pm 100$ & $n$-alkanes & $5280+520 /-310$ & 1 \\
\hline 2.95 & Poz-96324 & $7780 \pm 50$ & bulk & $7920+380 /-190$ & $2^{a}$ \\
\hline 3.64 & BE-12024.1.1 & $5830 \pm 130$ & $n$-alkanes & $6600+590 /-290$ & 1 \\
\hline 3.65 & Poz-94016 & $9250 \pm 80$ & bulk & $9660+550 /-250$ & $2^{\mathrm{a}}$ \\
\hline 3.99 & BE-13598.1.1 & $5780 \pm 120$ & charcoal & $6550+500 /-250$ & 1 \\
\hline 4.21 & Poz-98909 & $8750 \pm 170$ & bulk & $9060+900 /-480$ & $2^{\mathrm{a}}$ \\
\hline 4.57 & Poz-98910 & $6380 \pm 40$ & bulk & $6490+370 /-190$ & 2 \\
\hline 4.57 & BE-13597.1.1 & $5550 \pm 110$ & charcoal & $6310+450 /-210$ & 1 \\
\hline 4.57 & BE-13596.1.1 & $5800 \pm 120$ & charcoal & $6570^{+500} /-270$ & 1 \\
\hline 5.66 & Poz-94017 & $5740 \pm 40$ & bulk & $5800+370 /-200$ & $2^{b}$ \\
\hline 5.73 & BE-12023.1.1 & $6020 \pm 100$ & $n$-alkanes & $6830+470 /-230$ & 1 \\
\hline 7.74 & Poz-94018 & $6590 \pm 50$ & bulk & $6720+420 /-210$ & 2 \\
\hline 9.61 & Poz-94021 & $6850 \pm 50$ & bulk & $7020+410 /-210$ & 2 \\
\hline 9.63 & Poz-94020 & $6310 \pm 50$ & OMP & $7200+160 /-50$ & 1 \\
\hline 9.64 & BE-12022.1.1 & $6940 \pm 110$ & $n$-alkanes & $7750+370 /-180$ & 1 \\
\hline 11.19 & Poz-94022 & $6620 \pm 50$ & bulk & $6760+420 /-210$ & $2^{b}$ \\
\hline 12.95 & Poz-94023 & $8110 \pm 50$ & bulk & $8270+370 /-210$ & 2 \\
\hline 12.99 & BE-12021.1.1 & $7750 \pm 110$ & $n$-alkanes & $8510^{+460 /-190}$ & 1 \\
\hline
\end{tabular}

${ }^{\mathrm{a}}$ and ${ }^{\mathrm{b}}$ Samples that are too old and too young, respectively.

Table 3. Equivalent dose measurements on sample VOV16-1. 24 aliquots were measured $\left({ }^{*} n=\right.$ number of aliquots, a 25 th aliquot with a $\mathrm{D}_{\mathrm{e}}$ of $\sim 125$ Gy was excluded prior to analysis).

\begin{tabular}{lcccccccccc}
\hline $\begin{array}{l}\text { Average } \\
\text { sediment } \\
\text { depth }[\mathrm{m}]\end{array}$ & $\begin{array}{c}\text { Water } \\
\text { content } \\
(\%)\end{array}$ & $\begin{array}{c}\mathrm{U} \\
(\mathrm{ppm})\end{array}$ & $\begin{array}{c}\mathrm{Th} \\
(\mathrm{ppm})\end{array}$ & $\begin{array}{c}\mathrm{K} \\
(\%)\end{array}$ & $\begin{array}{c}\text { Dose rate } \\
\left(\mathrm{Gy} \mathrm{ka}^{-1}\right)\end{array}$ & $\begin{array}{c}\text { CAM De } \\
(\mathrm{Gy})(\mathrm{n})\end{array}$ & $\begin{array}{c}\text { CAM OD } \\
{[\%]}\end{array}$ & $\begin{array}{c}\text { MAM De } \\
(\mathrm{Gy})\end{array}$ & $\begin{array}{c}\text { CAM age } \\
(\mathrm{ka})\end{array}$ & $\begin{array}{c}\text { MAM age } \\
(\mathrm{ka})\end{array}$ \\
\hline 3.50 & 18 & 2.8 & 12.9 & 2.0 & $3.01 \pm 0.12$ & $31.0 \pm 2.8(24)^{*}$ & $40 \pm 6$ & $20.3 \pm 2.3$ & $10.3 \pm 1.0$ & $6.8 \pm 0.8$ \\
\hline
\end{tabular}

less negative values at the bottom followed by a trend to more negative values in Unit A. Unit B shows less negative

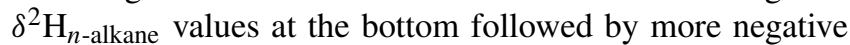

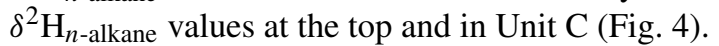

Paleontological analyses of the 33 macrofossil samples and 23 microfossil samples revealed 56 snail specimens representing six species. In descending order of abundance these are Turritella capensis (Krauss, 1848), which is clearly dom- inant, the rare Assiminea globulus (Conolly, 1939), Hydrobia sp., Natica tecta (Anton, 1839), Nassarius kraussianus (Dunker, 1846) and a fragment of an unidentified gastropod species (Fig. 5). The microfossil associations show a higher diversity. The dominating foraminifer taxon is $\mathrm{Am}$ monia parkinsoniana (d'Orbigny, 1839), followed by Quinqueloculina sp., and the rare Trochammina inflata (Montagu, 1808) and Haynesina sp. All other foraminifer taxa are 


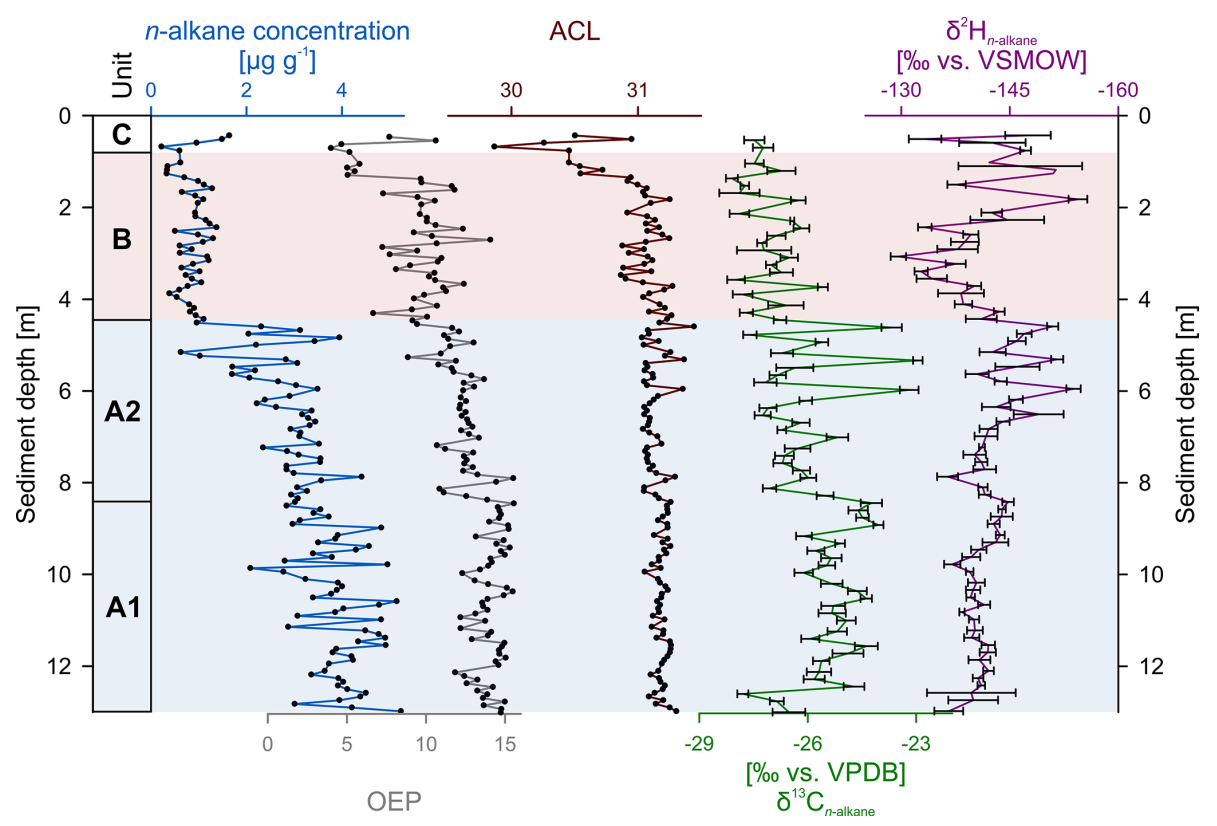

Figure 4. Concentration, odd-over-even predominance (OEP) and average chain length (ACL) of leaf wax $n$-alkanes and their stable isotopic composition for hydrogen $\left(\delta^{2} \mathrm{H}_{n \text {-alkane }}\right)$ and carbon $\left(\delta^{13} \mathrm{C}_{n \text {-alkane }}\right)$ of the Voëlvlei sediment record.

represented by only one test each (Bolivina sp., Cribroelphidium articulatum (d'Orbigny, 1839), Spirillina sp. and an unidentified trochamminid). The most abundant ostracod species are Sulcostocythere knysnaensis (Benson and Maddocks, 1964) and juveniles of Loxoconcha parameridionalis? (Benson and Maddocks, 1964); rare ostracods are a myodocopid specimen and juvenile Aglaiella valves as well as the freshwater species Sarscypridopsis aculeata (Costa, 1847), Cyprilla humilis (Sars, 1924) and an unidentifiable fragment of a larger species. Microfossils identified on a group level only are ephippia of cladocerans, gyrogonites of charophytes, Plumatella-like bryozoan statoblasts, mollusc and insect fragments, fish bone remains, fruits, and seeds as well as unidentifiable plant remains. Charcoal was found in large quantities in many samples.

Unit A1 shows a high diversity and contains most of the marine-brackish snails and high numbers of foraminifera. The ostracod fauna is dominated by brackish water taxa. Shell and fish bone fragments are abundant. Unit A2 looks similar to Unit A1 but is generally more variable in abundances and diversity. Macrofossils, i.e. marine-brackish snails, become rare. Salt marsh foraminifera, fruits and seeds occur for the first time. Units B and C lack marine-brackish snails, brackish ostracods and salt marsh foraminifera, and foraminifera in general are documented with a single test at the base of the zone only. In Unit B and C, freshwater ostracods occur for the first time and freshwater taxa in general dominate. Fragments of shells, plants, insects and charcoal disappear in Unit B and C (Fig. 5).

\section{Discussion}

\subsection{Chronostratigraphy}

Micropaleontological, organic and inorganic analyses show that three different depositional settings exist for the sediment sequence from Voëlvlei (Figs. 3, 5). In the lower part of the sequence (Unit A), the high concentrations of $\mathrm{Na}$, TOC and $\mathrm{N}$; high $\mathrm{Br} / \mathrm{Zr}$ ratios; and a marine/brackish gastropod species assemblage indicate a marine/brackish depositional setting from 13 to $4.51 \mathrm{~m}$ sediment depth (Figs. 2, $3,5)$. Corresponding reservoir-corrected bulk sediment ${ }^{14} \mathrm{C}$ ages as well as the terrestrial organic plant-macro particle and charcoal ${ }^{14} \mathrm{C}$ ages are all stratigraphically consistent and range from $8510+280 /-200$ to $6310+450 /-210$ cal BP suggesting that the sediments were rapidly deposited (Fig. 2). The overlap of the bulk and the plant-macro particle age and the bulk and charcoal ages confirm the suitability of the reservoir correction and application of the Marine20 calibration curve (Heaton et al., 2020) for bulk samples in Unit A. The only exception are the bulk ${ }^{14} \mathrm{C}$ ages at 11.19 and $5.66 \mathrm{~m}$ sediment depth, which are too young for their stratigraphic position. This is probably due to an increased input of terrestrial organic carbon during this time, indicated by corresponding high inputs of sand, reduced $\mathrm{Al}$ contents and lower $\mathrm{Al} / \mathrm{Zr}$ ratios (Figs. 2, 3). This likely added less ${ }^{14} \mathrm{C}$-depleted material, affecting the marine organic carbon stock and diluting the reservoir effect. As we cannot calculate the precise contribution of terrestrial organic carbon, these ${ }^{14} \mathrm{C}$ ages were excluded from the age model in a second modelling iteration (Heaton et al., 2020; Hogg et al., 2020) 


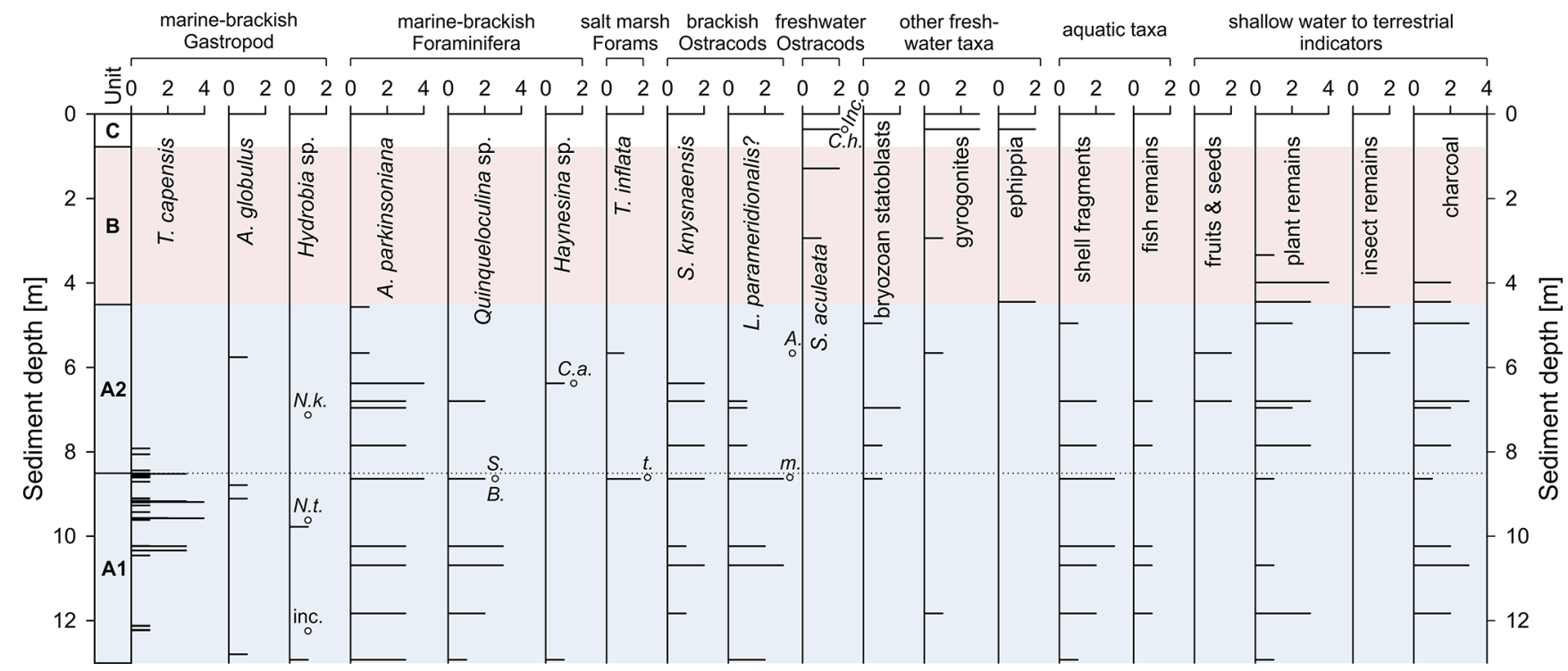

Figure 5. Distribution of micropaleontological taxa and charcoal in core VOV16. Units are based on distribution of micropaleontological taxa and lithological characteristics. Additional macrofossils were picked from the lowest part of the core where they are relatively abundant. All abundances are given semi-quantitatively ( 0 - absent, 1 - rare, 2 - common, 3 - abundant, 4 - very abundant). Single occurrences of taxa are indicated by empty circles and abbreviated name (Nassarius kraussianus, Natica tecta, Bolivina sp., Spirillina sp., Cribroelphidium articulatum, trochamminid foraminifer, Aglaiella, myodocopid ostracod, Cyprilla humilis).

(Fig. 2). At Voëlvlei, $n$-alkanes show a clear dominance of the $\mathrm{C}_{31}$ and $\mathrm{C}_{33}$ homologues and thus are of terrestrial origin (Boom et al., 2014; Chambers et al., 2014; Strobel et al., 2020). We therefore calibrated them with the terrestrial SHCal20 calibration curve. We note that a minor contribution of the shorter chain lengths $\left(<\mathrm{C}_{25}\right)$ to the dated compoundclass $n$-alkane samples, which are potentially synthesized by aquatic plants, for example, and may show a marine reservoir effect, leading to overly old ${ }^{14} \mathrm{C}$ ages when calibrated using a SHCal20 calibration curve. The aforementioned dominance of long-chain $n$-alkanes, however, makes a terrestrial origin likely and the distinct overlap with marine-calibrated and reservoir-corrected bulk ${ }^{14} \mathrm{C}$ ages support the application of the SHCal20 calibration curve to the compound-class $n$-alkane samples (Fig. 2).

At $4.51 \mathrm{~m}$ sediment depth, a distinct shift in the depositional setting occurred with decreasing $\mathrm{Na}$ concentrations, $\mathrm{Br} / \mathrm{Zr}$ ratios, and TOC and $\mathrm{N}$ concentrations, pointing towards a change from a marine/brackish environment to a fresher lacustrine environmental setting (Figs. 3, 5). At these depths bulk ${ }^{14} \mathrm{C}$ ages are much older than their stratigraphic position, possibly reflecting the deposition of degraded, pre aged sediments via erosion of old organic carbon from deeper soil horizons within the catchment (Bliedtner et al., 2020; Douglas et al., 2018; Haas et al., 2020). The OSL age (3.50 m sediment depth) is stratigraphically more consistent than the bulk ${ }^{14} \mathrm{C}$ ages. Since a MAM was applied it is likely that this age more closely reflects the timing of deposition, but the presence of partially or unbleached sand grains also potentially implies an input from older sediments at this time, supporting the interpretation of the bulk ${ }^{14} \mathrm{C}$ age overestimations. Compound-class $n$-alkane ${ }^{14} \mathrm{C}$ ages are stratigraphically consistent in Units B and C. We therefore infer that leaf waxes are derived from topsoils in the catchment and are rapidly deposited in the sediment archive (Bliedtner et al., 2020; Haas et al., 2017). Therefore, the incorporated climate signal should be close to that of the timing of deposition, and $n$-alkane-based proxies, i.e. $\delta^{2} \mathrm{H}_{n \text {-alkane and }}$ $\delta^{13} \mathrm{C}_{n \text {-alkane, yield paleoenvironmental information that can }}$ also be interpreted robustly.

\subsection{Marine influence and lake development}

South Africa, especially the southern Cape coast, is known to have experienced distinct environmental changes related to relative sea level fluctuations during the Holocene (Cooper et al., 2018; Kirsten et al., 2018b; Marker and Miller, 1993; Reddering, 1988; Wündsch et al., 2018, 2016a). Voëlvlei can contribute to our understanding of sea level changes during the Holocene due to its present location at an elevation of $5 \mathrm{~m}$ a.s.l. and the high temporal resolution of its Early and Middle Holocene depositional record. Inferred from lithological characteristics, paleoecological and elemental analyses, which indicate variable intrusion of marine water, the record suggests three eco-zones, of which one can be subdivided in two subzones (Units A1, A2, and B and C) (Fig. 6).

During the period between $8440+200 /-250$ and $7070+160 /-200$ cal BP (Unit A1), the dominant gastropod is Turritella capensis, which is a common species in sandy coastal lagoons in South Africa today (Branch et 


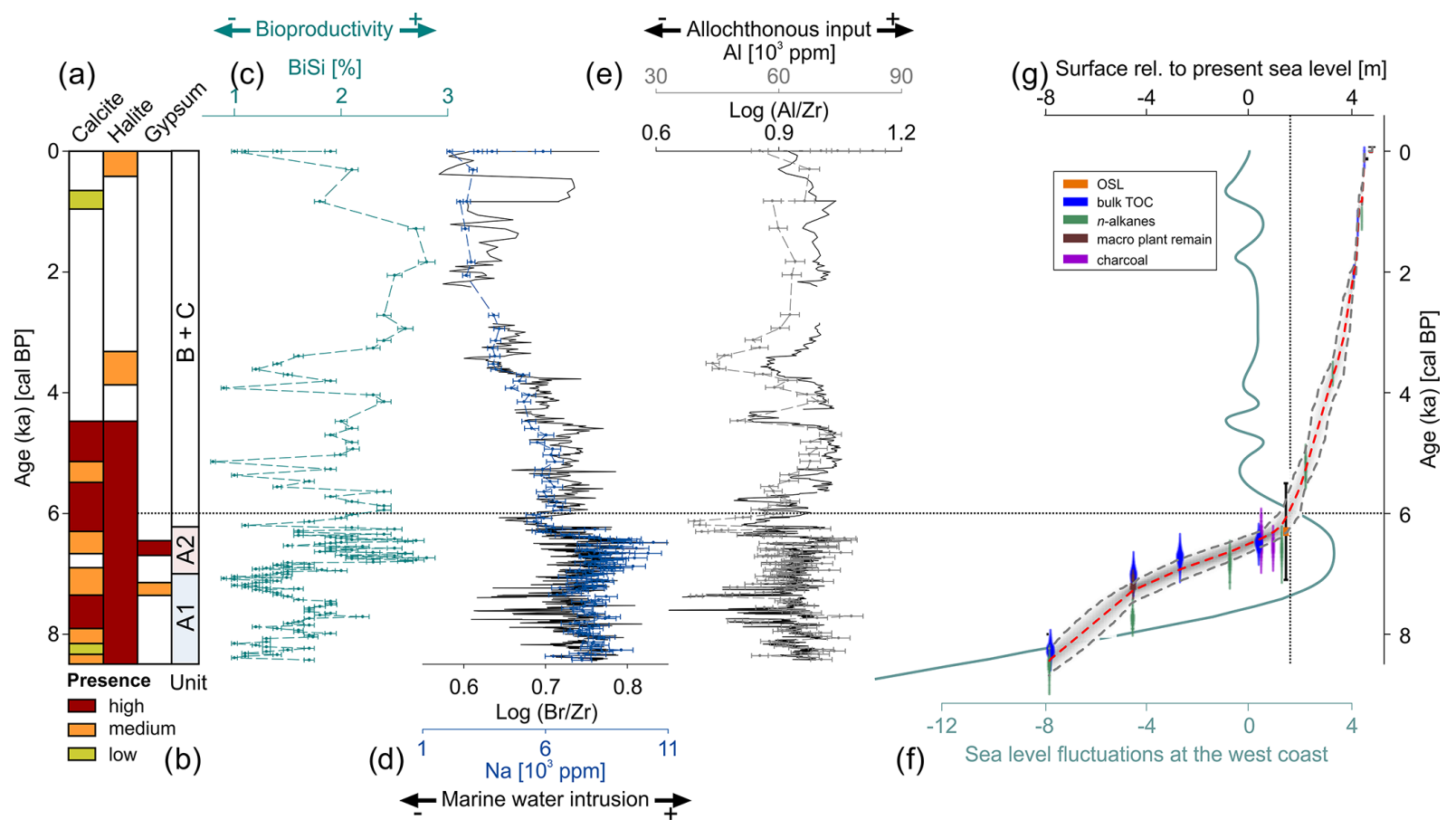

Figure 6. (a) Occurrence of selected mineral components in the VOV16 sediment record, (b) lithological and paleoecological units (A1 subtidal marine-brackish, A2 - intratidal brackish, B+C freshwater to terrestrial), (c) biogenic silica (BiSi) content, (d) Na content and Log (Br/Zr) ratios, (e) Al content and Log (Al/Zr) ratios from Voëlvlei. (f) Sea level curve for the west coast of South Africa (Compton, 2006; Cooper et al., 2018) and (g) the lake floor of Voëlvlei relative to the present sea level.

al., 2010), preferring the mid-intertidal zone (Walters and Griffiths, 1987) (Figs. 5, 6). The rarer gastropod Assiminea globulus is known to be abundant on upper intertidal mudflats of South African estuaries (Barnes, 2018), whereas the small gastropod Hydrobia prefers the upper salt marshes of South Africa (Branch et al., 2010). The single occurrences of Natica tecta and Nassarius kraussianus point to estuarine mudflats (Branch et al., 2010) (Figs. 5, 6). Abundant brackish water ostracods and foraminifera indicate permanent water cover at the coring site during this period. In summary, these fauna reflect an estuarine and shallow subtidal environment close to intertidal mudflats. The abundance of plant remains and fragments of shells and fish bones point to shallow water as well. Therefore, we assume the respective core depths reflect an elevation slightly below the past sea level, which is in line with the paleo-surface of Lake Voëlvlei, i.e. 8.0 to $3.5 \mathrm{~m}$ below present sea level (b.s.l.) from $8440+200 /-250$ to $7070+160 /-200$ cal BP (Fig. 6). The low diversity of foraminifera is typical for lower salinity conditions; the dominant small and unornamented Ammonia species, Quinqueloculina and Haynesina, are consistent with this brackish water inference (Murray, 2006) (Figs. 5, 6). The same applies to the brackish water ostracod fauna, which are dominated by the estuarine species Sulcostocythere knysnaensis and Loxoconcha parameridionalis (Fürstenberg et al., 2017; Kirsten et al., 2018a) (Figs. 5, 6). The complete absence of open marine microfossils, especially planktonic foraminifera and echinoderm fragments, indicates an inner estuarine position in the core locality without direct marine inflow, even under high-energy conditions. The few bryozoan statoblasts and gyrogonites of charophytes all derive from freshwater environments (Frenzel, 2019; Kirsten et al., 2018a) and point to an unconfined exchange with river water. The highest salinity for the entire core is probably reached at $7090+170 /-200$ cal BP when the abundance and diversity of the foraminifera reach a maximum and a myodocopid ostracod was found (Figs. 5, 6). The coring position was ca. $3.65 \mathrm{~m}$ b.s.l. during this time (Fig. 6). Therefore, sea level was likely at the present height or slightly lower.

Between $7070^{+170} /-200$ and $6420^{+130} /-140$ cal BP (Unit A2), continued inner estuarine, brackish water conditions are indicated by a similar assemblage of taxa as observed in Unit A1. Intertidal gastropods typical for Unit A1, however, are now very rare, suggesting decreasing tidal influence and probably decreasing salinity (Figs. 5, 6). Salt marsh foraminifera occur only in Unit A2, albeit in low numbers (Fig. 6). This points to a very shallow water depth under marine/brackish conditions and a close shoreline (Strachan et al., 2017), which is in good agreement with the occurrence of fruits and seeds (only occurring in this unit), and the abundant plant remains. However, the high variability in the abundance of many taxa indicates unstable 
conditions compared to Unit A1. Freshwater inflow is implied by floating bryozoan statoblasts and charophyte gyrogonites (Frenzel, 2019) (Figs. 5, 6). The respective paleosurface of Lake Voëlvlei was ca. $3.5 \mathrm{~m}$ b.s.l. to $0.5 \mathrm{~m}$ a.s.1. from $7070^{+170 /-200}$ to $6420^{+130} /-140$ cal BP (Fig. 6), indicating a sea level higher than the present during this time.

Elemental $(\mathrm{Br} / \mathrm{Zr}$ ratios, $\mathrm{Na}$ contents) and mineralogical data support phases of marine water intrusion at Voëlvlei. Bromide salts are common in sea water but occur in very low concentrations in freshwater systems (Song and Müller, 1993). In aqueous environments the dominant species is $\mathrm{Br}^{-}$, which substitutes the salt constituent chloride $\left(\mathrm{Cl}^{-}\right)$in the sea salt lattice during crystallization (Ullman, 1995). Halite $(\mathrm{NaCl})$ also originates from marine waters, and thus $\mathrm{Br}, \mathrm{Na}$ and halite can be used as indicators of marine water intrusion (Babel and Schreiber, 2014; Olsen et al., 2012; Wündsch et al., 2018). High values of the marine indicators from the elemental analysis (Na, $\mathrm{Br} / \mathrm{Zr}$ ratios) and the presence of halite in the sediments are in good agreement with our micropaleontological data indicating marine water intrusions in Units $\mathrm{A} 1$ and $\mathrm{A} 2$ $(8440+200 /-250$ to $6420+130 /-140$ cal BP; Fig. 6$)$. Furthermore, the occurrence of calcite in both units as well as gypsum from $7260+110 /-210$ to $7180+150 /-200$ cal BP and $6590+150 /-160$ to $6550+150 /-160$ cal BP also points towards shallow water conditions as also indicated by the micropaleontology results (Fig. 6). Such shallow water conditions support bioproductivity (BiSi) increases in Unit A1 and A2 which reached a maximum at ca. $6740+170 /-170$ cal BP (Fig. 6). The elevation of the lake floor rapidly increases from ca. $8 \mathrm{~m}$ b.s.l. at $8440+200 /-250$ (base of the VOV16 record) to ca. $0.5 \mathrm{~m}$ a.s.1. at $6420+130 /-140$ cal BP (Unit A1 and A2; Fig. 6). Therefore, results imply a higher sea level compared to today until $6420+130 /-140$ cal BP and thus lend further support for a proposed local/regional Holocene relative sea level maximum of about +3.8 ma.s.l. (ca. 7600 $5800 \mathrm{cal}$ BP) (Cooper et al., 2018) on the southern Cape.

The micropaleontological associations of Units B and C $(6420+130 /-140$ cal BP until today) are completely different from those of Unit A1 and A2 (Figs. 5, 6). Many samples are devoid of microfossils and freshwater taxa dominate other samples. One single test of the foraminifer Ammonia sp. found in the lowermost part of unit B is the only brackish water taxon (Murray, 2006). This was likely reworked from older sediments where this species is very abundant (Figs. 5, 6). Therefore, we assume freshwater or athalassic conditions for samples with aquatic taxa. New to Unit B and C are the freshwater ostracod species Sarscypridopsis aculeata and ephippia of cladocerans, which are typical of non-permanent water bodies (Frenzel, 2019; Meisch, 2000). They likely reflect the transformation of Voëlvlei to a non-permanent lake and terrestrial habitat. The lower part of Unit B contains variable amounts of plant remains and charcoal, indicating river transport. Their later disappearance points to an isolation of the basin while silting up.
Decreasing elemental marine indicators $(\mathrm{Na}, \mathrm{Br} / \mathrm{Zr}$ ratios) support reduced intrusion of marine waters from $6420+130 /-140$ cal BP (Fig. 6). Sedimentation rates markedly decrease while the occurrence of calcite $(6290+240 /-150-4590+590 /-550$ cal BP) further supports shallow water conditions in Units B and C (Fig. 6). While further silting up led to the isolation of the sediment surface above the present sea level $(0 \mathrm{~m}$ a.s.l.) from $6510^{+140} /-150$ cal BP (Fig. 6), marine water intrusion was likely absent from $4300+490 /-570$ cal BP when the sediment surface reached $3 \mathrm{~m}$ a.sl. This is based on considering a still elevated sea level of about $+1 \mathrm{~m}$ a.sl. (5300-4200 cal BP) (Cooper et al., 2018) and a tidal range comparable to today (neap tide: $0.6-0.8 \mathrm{~m}$, spring tide: $1.8-2 \mathrm{~m}$ ) (Rautenbach et al., 2019).

Overall, the results only provide evidence of marine water intrusion in the Voëlvlei system rather than sea level index points and thus cannot be used to generate or corroborate an exact relative sea-level curve (e.g. Compton, 2006; Cooper et al., 2018). However, in comparison to local/regional records the results of this study are in line with the findings from Eilandvlei (Kirsten et al., 2018b; Wündsch et al., 2018) and Groenvlei (Wündsch et al., 2016a), which indicate a rising sea level during the Early Holocene and a high stand during the Middle Holocene. The proxies used in this study generally support the assumed sea-level evolution at the southern Cape coast of South Africa (Kirsten et al., 2018b; Marker and Miller, 1993; Reddering, 1988; Wündsch et al., 2018, 2016a). In (supra-)regional comparison, these results are also in line with studies from the west coast of South Africa (Baxter and Meadows, 1999; Carr et al., 2015; Kirsten et al., 2020) and Namibia (Compton, 2006), as reviewed in Cooper et al. (2018), showing a rapid sea level rise to a maximum of $+3.8 \mathrm{~m}$ a.s.l. (ca. $7600-5800 \mathrm{cal} \mathrm{BP}$ ), followed by a decrease to $+1 \mathrm{~m}$ a.s.l. (5300-4200 cal BP) and a relatively constant sea level, comparable to the present, thereafter (Fig. 6).

\subsection{Paleoenvironmental and paleoclimate evolution}

The main driver of the $\delta^{2} \mathrm{H}_{n \text {-alkane signal at Voëlvlei is }}$ the $\delta^{2} \mathrm{H}$ variability of the precipitation source (Strobel et al., 2020) although it has to be noted that variations in the vegetation composition, e.g. varying biosynthetic fractionation, evapotranspirative enrichment and water use efficiency, may all potentially alter the $\delta^{2} \mathrm{H}_{n \text {-alkane }}$ signal (Hou et al., 2007; Sachse et al., 2012). However, modern precipitation suggests that westerly-derived precipitation is ${ }^{2} \mathrm{H}-$ depleted and easterly-derived precipitation is ${ }^{2} \mathrm{H}$-enriched (Bowen, 2018; Bowen et al., 2005; Braun et al., 2017; Harris et al., 2010; Table 1). This is also imprinted in modern reference material from topsoils (Hahn et al., 2018; Strobel et al., 2020) (mean $\delta^{2} \mathrm{H}_{n \text {-alkane values from topsoils }}$ from WRZ and SRZ are $-145 \pm 10 \%$ and $-135 \pm 10 \%$, respectively), pointing to the "source effect" as the domi- 
nant driver of the $\delta^{2} \mathrm{H}_{n \text {-alkane }}$ signal at Voëlvlei. $\delta^{2} \mathrm{H}_{n \text {-alkane }}$ values from Voëlvlei are moderate from $8440+200 /-250$ to $7070+160 /-200$ cal BP, which imply a year-round precipitation regime, i.e. contributions of both westerly- and easterlyderived precipitation (Fig. 7a).

Year-round precipitation is accompanied by less neg-

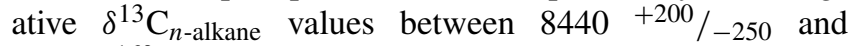
$7070+160 /-200$ cal BP, likely indicating overall dry conditions for this period at Voëlvlei (Fig. 7e). These dry conditions potentially led to a sparse vegetation cover and runoff (induced by occasional events), which likely carried extremely variable grain sizes and amounts of allochthonous input ( $\mathrm{Al}$ concentration, $\mathrm{Al} / \mathrm{Zr}$ ratios) (Fig. 7g). Minimum values in $\mathrm{Al}$ concentrations and $\mathrm{Al} / \mathrm{Zr}$ ratios are assumed to be caused by layers consisting almost exclusively of sand $\left(\mathrm{SiO}_{2}\right)$ and thus imply high allochthonous inputs (Figs. 2, 7h) at this time. Similarly at Vankervelsvlei, input of reworked soil material during this time is interpreted to be the result of low vegetation cover in the catchment (Strobel et al., 2019). This interpretation of dry conditions between $8440+200 /-250$ and $7070^{+160} /-200$ cal BP is also in line with the findings from Eilandvlei, where low Afrotemperate forest (AFT) pollen percentages are interpreted as overall dry conditions between ca. 8500 and 7000 cal BP (Quick et al., 2018) (Fig. 7d), and a study at Seweweekspoort, where less positive $\delta^{15} \mathrm{~N}$ values are also interpreted to indicate moderately dry conditions (Chase et al., 2017) (Fig. 7c) resulting in a consistent moisture signal in the YRZ during this time.

At $7020+170 /-200$ cal BP, moister conditions are indicated by a distinct shift to more negative $\delta^{13} \mathrm{C}_{n \text {-alkane values }}$ and evidence for increased allochthonous inputs (Al content, $\mathrm{Al} / \mathrm{Zr}$ ratios), which lasts until the present. However, there are decreases in allochthonous inputs from $6420+130 /-140$ to $6080+320 /-240 \mathrm{calBP}$, and at $4480+580 /-540$ and $3530^{+500} /-470$ cal BP (Fig. $7 \mathrm{~g}$ ). The latter event is accompanied by distinctly negative $\delta^{13} \mathrm{C}$ values (Fig. 7e) whereas the earlier one only shows slightly more negative values. This potentially indicates a denser vegetation cover and reduced runoff-induced sediment input, which are supported by the presence of freshwater taxa during this time (Fig. 5). However, drier conditions inferred from reduced allochthonous input could also be possible due to drought-induced changes of the vegetation composition indicated by a higher proportion of plants using CAM metabolism. These could possibly reduce drought stress and therefore the influence of water use efficiency to ${ }^{13} \mathrm{C}$-enrichment in the $n$-alkanes (Diefendorf and Freimuth, 2017). Overall it is difficult to interpret the variations in the core between $4480+580 /-540$ and $3530+500 /-470 \mathrm{cal}$ BP. They interrupt a trend towards moister conditions but cannot be ultimately attributed to moister or drier conditions.

Noticeable in the record are three data points at $6670+170 /-170,6560+150 /-160$ and $6440+130 /-140$ cal BP

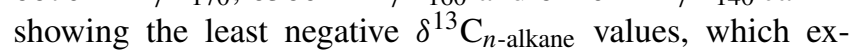
ceed all other measurements and are accompanied by dis-

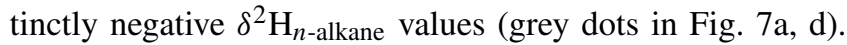
For those three samples, the climate signal is possibly overprinted by local effects of plants that grow at shallower water depths and/or at the shoreline of the lake. While less neg-

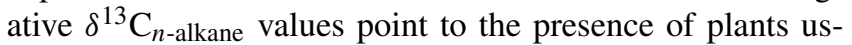
ing $\mathrm{C}_{4}$ and/or CAM metabolism (Boom et al., 2014; Carr et al., 2015; Diefendorf and Freimuth, 2017), the $\delta^{2} \mathrm{H}_{n \text {-alkane }}$ signal with more negative values can be biased by the photosynthetic mode and also salinity (Aichner et al., 2017; Feakins and Sessions, 2010; Ladd and Sachs, 2012; Sachse et al., 2012). Therefore, disentangling the regional climate and local overprinting is challenging for the three aforementioned data points. However, since allochthonous input is high (Al concentration, $\mathrm{Al} / \mathrm{Zr}$ ratios; Fig. $7 \mathrm{~g}$ ), we hypothesize overall moist conditions since $7020^{+170} /-200 \mathrm{cal} \mathrm{BP}$.

Moister conditions are accompanied by more neg-

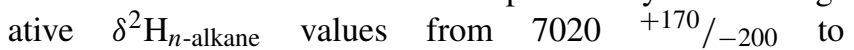
$6420+130 /-140$ cal BP, which are likely indicative of an increased contribution of westerly-derived precipitation (Fig. 7a). At the same time as the aforementioned reduction of the allochthonous inputs, there is also a marked shift to

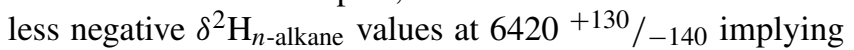
an increased contribution of easterly-derived precipitation

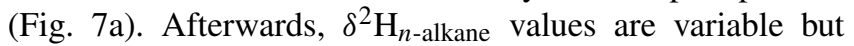
have an overall trend from less negative to more negative

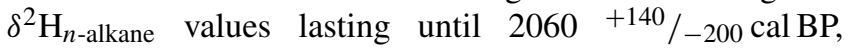
which is likely suggest a return from an easterly- to a more dominantly westerly-derived precipitation regime (Fig. 7a). However, already at the beginning, this period is interrupted by a short phase of somewhat more negative values from $5560+430 /-470$ to $5150+340 /-330$, indicating more westerly-derived precipitation (Fig. 7a). From $2060+140 /-200$ cal BP until the present, less nega-

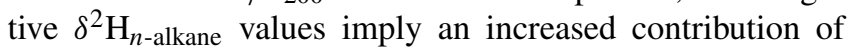
easterly-derived precipitation (Fig. 7a), which occurs within a trend towards moister conditions $\left(\delta^{13} \mathrm{C}_{n \text {-alkane }}\right)$ (Fig. 7e).

Moist conditions between ca. 7000 and ca. 4700 cal BP are in line with studies from the central southern Cape coast (Quick et al., 2018; Strobel et al., 2019; Wündsch et al., 2018). At ca. $4700 \mathrm{cal} \mathrm{BP}$, a rapid shift in climate was also detected in numerous studies located in the YRZ. In the Wilderness area, dry conditions and low wind-driven evapotranspiration were reconstructed during this time (Quick et al., 2018; Strobel et al., 2019; Wündsch et al., 2018) (Fig. 7d). After $4700 \mathrm{cal} \mathrm{BP}$, the overall trend in increasing moisture availability at the central southern Cape coast is again in line with our findings at Voëlvlei (du Plessis et al., 2020; Quick et al., 2018; Strobel et al., 2019; Wünd-

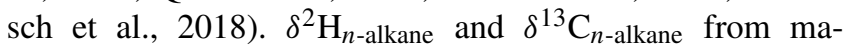
rine sediments recovered off the mouth of the Gouritz River (GeoB18308-2; Fig. 1) show a very similar pattern to Voëlvlei over the past $4000 \mathrm{cal}$ BP (Hahn et al., 2017) (Fig. 7). Those findings thus support our findings from Voëlvlei and suggest a consistent regional picture for the southern Cape coast. 


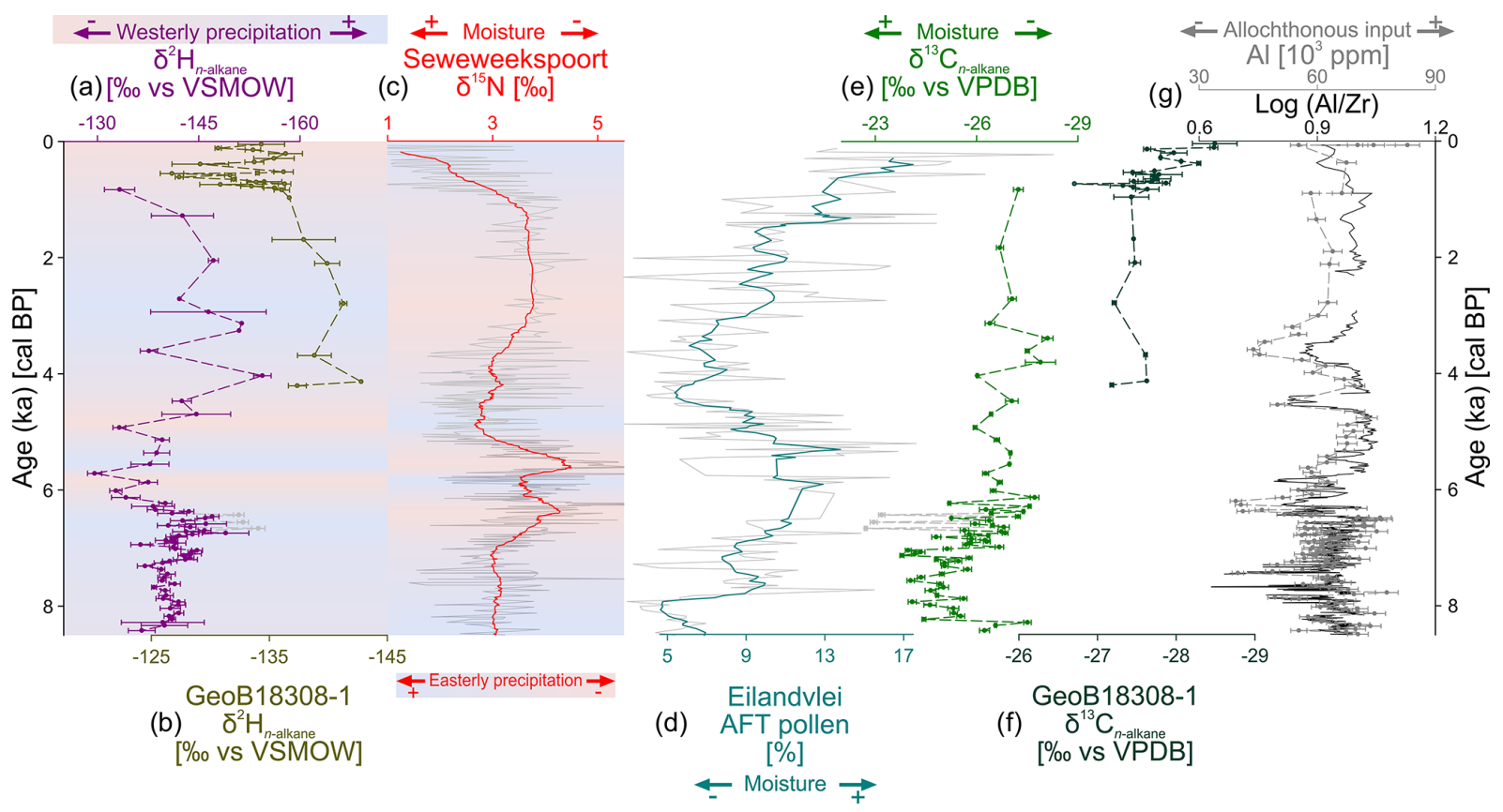

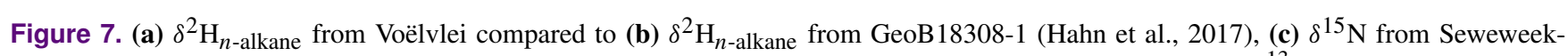

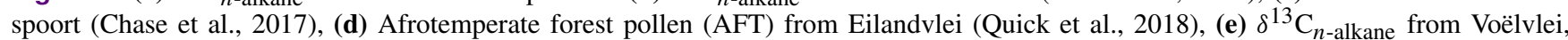

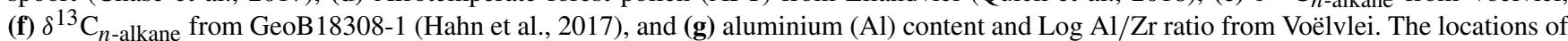
the studies are depicted in Fig. 1.

At Seweweekspoort, ca. $100 \mathrm{~km}$ inland, $\delta^{15} \mathrm{~N}$ values fol-

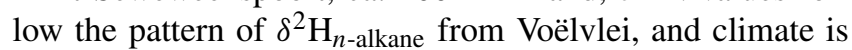
thought to have been dry from ca. 7000 to ca. $4700 \mathrm{cal} \mathrm{BP}$ and ca. 3000 to ca. $1000 \mathrm{cal} \mathrm{BP}$ due to reduced easterly-related precipitation (Chase et al., 2017) (Fig. 7c). Intense short-term variations to wetter conditions at Seweweekspoort contradict the aforementioned results from the Wilderness area at ca. 5700 and ca. 4900 cal BP but are well reflected by spikes in the $\delta^{2} \mathrm{H}_{n \text {-alkane }}$ record from Voëlvlei which shows shifts to-

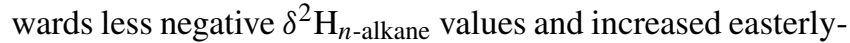
related precipitation contributions (Fig. 7a, c).

In this context, previous studies hypothesize that the nondominant component of the temperate (westerly)/tropical (easterly) dynamic determines hydro-climatic variability in southern Africa (e.g. Chase et al., 2017, 2015). More precisely, this means that although easterly-derived (westerlyderived) precipitation is relatively low in the western (eastern) parts of the YRZ, variability in the overall moisture signal is thought to strongly depend on moisture contribution from this minor component (e.g. Chase et al., 2017,

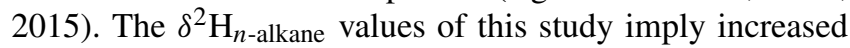
westerly-derived precipitation during drier phases at Seweweekspoot and increased easterly-derived precipitation during moister phases at Seweweekspoort (Fig. 7c), at a time generally characterized by a trend towards moister conditions at Voëlvlei (Fig. 7e). Moist conditions between 7000 and 5500 cal BP were also found in the north-southtrending Cape Fold Mountains in the Western Cape (Chase et al., 2019, and references therein), indicating an overall moist period for south-western South Africa during this time which is perfectly in line with the increased westerly precipitation contribution at Voëlvlei.

However, an opposite pattern is proposed to exist between sites located inland of the Cape Fold mountains (e.g. Seweweekspoort, Katbakkies Pass) and coastal sites from the southern Cape coast (e.g. Eilandvlei) (Chase and Quick, 2018; Quick et al., 2018). There are still discrepancies due to the comparison of different proxies in these studies compared to those from the southern Cape coast. Comparing our $\delta^{2} \mathrm{H}_{n \text {-alkane }}$ record from Voëlvlei, which is representative of fluctuations in the major moisture sources, with the $\delta^{15} \mathrm{~N}$ from Seweweekspoort (Chase et al., 2017), in detail many similarities are apparent, confirming the assumption that hydrological variations at Seweweekspoort are distinctly driven by variations in easterly-derived precipitation. However, on the South Coast of South Africa including Voëlvlei the overall moisture evolution is not restricted to one moisture source and thus driven by a combination of both westerly- and easterly-derived precipitation.

The topmost sediments of Voëlvlei mainly consist of two fluvial flooding events (at $830+110 /-110$ and $10^{+10} /-10$ cal BP) which deposited large amounts of sediment (ca. 15 and ca. $30 \mathrm{~cm}$, respectively; Figs. 2, 7). Considering the chronological uncertainties (dating and modelling errors), the most recent flooding event can likely be associated with the so called "Laingsburg flood" from January 1981 
(Damm and Hagedorn, 2010 and references therein). In marine sediments recovered off the mouth of the Gouritz River (GeoB18308-2; Fig. 1) major flooding events were detected between 650 and 300 cal BP and thus support our findings (Hahn et al., 2017).

\section{Conclusions}

Our multi-proxy record from Voëlvlei provides new insights into the sea level and paleoclimate history of the past $8.5 \mathrm{ka}$ at the southern Cape Coast. Various dating approaches including OSL and ${ }^{14} \mathrm{C}$ of bulk TOC, organic macrofossils, charcoal and $n$-alkanes were applied to establish a robust chronology. Three temporal eco-zones can be characterized for Voëlvlei. These are related to sea level variations and are in line with results of regional investigations in implying a subtidal marine-brackish followed by an intratidal brackish system from $8440+200 /-250$ to $6420^{+130} /-140$ cal BP, and a freshwater to terrestrial system due to silting up of Voëlvlei thereafter. In terms of climate, the combined biomarkersedimentological approach allows the additional identification of changing precipitation sources, in combination with an estimation of moisture availability. Dry conditions accompanied by a year-round precipitation contribution prevail from $8440+200 /-250$ to $7070+160 /-200$ cal BP followed by moister conditions and more westerly-derived precipitation contributions from $7070+160 /-200$ to $6420+130 /-140$ cal BP, This was followed by a distinct shift to an easterly dominance at $6420 \mathrm{cal} \mathrm{BP}$, before an overall trend to a westerly dominance, which lasted until $2060 \mathrm{cal}$ BP. This is followed by a trend towards an easterly dominance, but both phases show several intense short-term variations.

These results are in good agreement with previous studies with regard to sea-level change on the western and southern coast of South Africa. The paleohydrological evolution of Voëlvlei is comparable to previous investigations from the Southern Cape coast during the past $8.5 \mathrm{ka}$, demonstrating an interplay of both westerly- and easterly-derived precipitation contribution. Hydrological variations at Seweweekspoort, located within the interior of central southern South Africa, a region hypothesized to show distinct hydroclimatic trends (relative to the coastal zones) through the Holocene, show

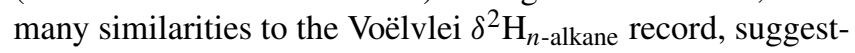
ing a need to further consider in more detail regional-scale complexities and coastal-inland contrasts in paleoclimatic trajectories. Thus, the Voëlvlei $\delta^{2} \mathrm{H}_{n \text {-alkane }}$ record provides valuable insights into the source of precipitation at the Southern Cape coast during the past $8.5 \mathrm{ka}$.

Data availability. All data within the paper will be available at PANGAEA.
Supplement. The supplement related to this article is available online at: https://doi.org/10.5194/cp-17-1567-2021-supplement.

Author contributions. PS, RZ and TH designed the study. PS, $\mathrm{MB}, \mathrm{ASC}, \mathrm{PF}, \mathrm{BK}, \mathrm{GS}$, JS and SS carried out the laboratory and analytical analyses. All authors contributed to the writing of the paper and data discussion.

Competing interests. The authors declare that they have no conflict of interest.

Disclaimer. Publisher's note: Copernicus Publications remains neutral with regard to jurisdictional claims in published maps and institutional affiliations.

Acknowledgements. Sediment cores were recovered within the RAiN project funded by the German Federal Ministry of Education and Research (BMBF). Paul Strobel gratefully acknowledges the support by a fellowship from the state of Thuringia (Landesgraduiertenstipendium). Particularly acknowledged are Cristopher Berndt, Nico Blaubach, Tobias Eggert, Christian Gregori, Patricia Rauh, Mike Steinich and Magdalena Wagner for assistance in the lab. Gerhard Daut is thanked for supporting the XRD measurements. Nadia du Plessis, Jussi Baade, Sayed Hess, Christian Gregori, Roland Mäusbacher and Michael E. Meadows are thanked for their fieldwork contributions and constructive discussions. The participants of the 2019 course on Paleoenvironmental Analysis at Friedrich Schiller University Jena supported us in micropaleontological sample preparation and picking of microfossils for an initial batch of subsamples.

Financial support. This study was funded by the German Research Foundation (DFG) (grant nos. HA 5089/11-1 and ZE 860/61).

Review statement. This paper was edited by Keely Mills and reviewed by Hayley Cawthra and three anonymous referees.

\section{References}

Aichner, B., Hilt, S., Périllon, C., Gillefalk, M., and Sachse, D.: Biosynthetic hydrogen isotopic fractionation factors during lipid synthesis in submerged aquatic macrophytes: Effect of groundwater discharge and salinity, Org. Geochem., 113, 10-16, 2017.

Aitken, M. J.: Thermoluminescence Dating, Academic Press, London, ISBN: 9780120463800, 1985.

Bąbel, M. and Schreiber, B. C.: Geochemistry of Evaporites and Evolution of Seawater, in: Treatise on Geochemistry, 2nd edn., edited by: Holland, H. D. and Turekian, K. K., Elsevier, Oxford, 483-560, https://doi.org/10.1016/B978-0-08095975-7.00718-X, 2014. 
Barnes, R. S. K.: Little-known and phylogenetically obscure South African estuarine microgastropods (Mollusca: Truncatelloidea) as living animals, J. Nat. Hist., 52, 87-113, 2018.

Baxter, A. J. and Meadows, M. E.: Evidence for Holocene sea level change at Verlorenvlei, Western Cape, South Africa, Quatern. Int., 56, 65-79, 1999.

Bell, W. T.: Thermoluminescence dating: radiation dose rate data, Archaeometry, 21, 243-245, 1979.

Benson, R. H. and Maddocks, R. F.: Recent ostracodes of Knysna Estuary, Cape Province, Union of South Africa, The University of Kansas Palaeontological Contributions, article no. 5, 1964.

Birch, G. F., du Plessis, A., and Willis, J. P.: Offshore and onland geological and geophysical investigation in the Wilderness Lakes Region, Transactions of the Geological Society of South Africa, 81, 339-352, 1978.

Blaauw, M. and Christen, J. A.: Flexible Paleoclimate Age-Depth Models Using an Autoregressive Gamma Process, Bayesian Anal., 6, 457-474, 2011.

Bliedtner, M., von Suchodoletz, H., Schäfer, I., Welte, C., Salazar, G., Szidat, S., Haas, M., Dubois, N., and Zech, R.: Age and origin of leaf wax $n$-alkanes in fluvial sediment-paleosol sequences and implications for paleoenvironmental reconstructions, Hydrol. Earth Syst. Sci., 24, 2105-2120, https://doi.org/10.5194/hess-242105-2020, 2020.

Bliedtner, M., Zech, R., Kühn, P., Schneider, B., Zielhofer, C., and von Suchodoletz, H.: The potential of leaf wax biomarkers from fluvial soil-sediment sequences for paleovegetation reconstructions - Upper Alazani River, central southern Greater Caucasus (Georgia), Quaternary Sci. Rev., 196, 62-79, 2018.

Boom, A., Carr, A. S., Chase, B. M., Grimes, H. L., and Meadows, M. E.: Leaf wax $n$-alkanes and $\delta^{13} \mathrm{C}$ values of CAM plants from arid southwest Africa, Org. Geochem., 67, 99-102, 2014.

Bowen, G. J.: The Online Isotopes in Precipitation Calculator, version 3.1, available at: http://www.waterisotopes.org, last access: 12 February 2018.

Bowen, G. J., Wassenaar, L. I., and Hobson, K. A.: Global application of stable hydrogen and oxygen isotopes to wildlife forensics, Oecologia, 143, 337-348, 2005.

Branch, G. M., Griffiths, C. L., Branch, M. L., and Beckley, L. E.: Two oceans: A guide to the marine life of southern Africa, Struik Nature, Cape Town, ISBN: 9781770077720, 2010.

Braun, K., Bar-Matthews, M., Ayalon, A., Zilberman, T., and Matthews, A.: Rainfall isotopic variability at the intersection between winter and summer rainfall regimes in coastal South Africa (Mossel Bay, Western Cape Province), S. Afr. J. Geol., 120, 323-340, 2017.

Braun, K., Bar-Matthews, M., Matthews, A., Ayalon, A., Zilberman, T., Cowling, R. M., Fisher, E. C., Herries, A. I. R., Brink, J. S., and Marean, C. W.: Comparison of climate and environment on the edge of the Palaeo-Agulhas Plain to the Little Karoo (South Africa) in Marine Isotope Stages 5-3 as indicated by speleothems, Quaternary Sci. Rev., 235, 105803, https://doi.org/10.1016/j.quascirev.2019.06.025, 2020.

Braun, K., Bar-Matthews, M., Matthews, A., Ayalon, A., Cowling, R. M., Karkanas, P., Fisher, E. C., Dyez, K., Zilberman, T., and Marean, C. W.: Late Pleistocene records of speleothem stable isotopic compositions from Pinnacle Point on the South African south coast, Quaternary Res., 91, 265-288, 2018.
Buggle, B., Wiesenberg, G. L. B., and Glaser, B.: Is there a possibility to correct fossil $n$-alkane data for postsedimentary alteration effects?, Appl. Geochem., 25, 947-957, 2010.

Burrow, C.: Calc_MinDose(): Apply the (un-)logged minimum age model (MAM) after Galbraith et al. (1999) to a given De Distribution. Function version 0.4.4, in: Luminescence: Comprehensive Luminescence Dating Data Analysis, edited by: Kreutzer, S., Burrow, C. Dietze, M., Fuchs, M. C., Schmidt, C., Fischer, M., and Friedrich, J., R package version 0.9.3, 2019. 2019.

Carr, A. S., Boom, A., Chase, B. M., Meadows, M. E., and Grimes, H. L.: Holocene sea level and environmental change on the west coast of South Africa: evidence from plant biomarkers, stable isotopes and pollen, J. Paleolimnol., 53, 415-432, 2015.

Chambers, F. M., Brain, S. A., Mauquoy, D., McCarroll, J., and Daley, T.: The "Little Ice Age- in the Southern Hemisphere in the context of the last 3000 years: Peat-based proxy-climate data from Tierra del Fuego, Holocene, 24, 1649-1656, 2014.

Chase, B. M. and Meadows, M. E.: Late Quaternary dynamics of southern Africa's winter rainfall zone, Earth-Sci. Rev., 84, 103138, 2007.

Chase, B. M. and Quick, L. J.: Influence of Agulhas forcing of Holocene climate change in South Africa's southern Cape, Quaternary Res., 90, 303-309, 2018.

Chase, B. M., Lim, S., Chevalier, M., Boom, A., Carr, A. S., Meadows, M. E., and Reimer, P. J.: Influence of tropical easterlies in southern Africa's winter rainfall zone during the Holocene, Quaternary Sci. Rev., 107, 138-148, 2015.

Chase, B. M., Chevalier, M., Boom, A., and Carr, A. S.: The dynamic relationship between temperate and tropical circulation systems across South Africa since the last glacial maximum, Quaternary Sci. Rev., 174, 54-62, 2017.

Chase, B. M., Faith, J. T., Mackay, A., Chevalier, M., Carr, A. S., Boom, A., Lim, S., and Reimer, P. J.: Climatic controls on Later Stone Age human adaptation in Africa's southern Cape, J. Hum. Evol., 114, 35-44, 2018.

Chase, B. M., Boom, A., Carr, A. S., Chevalier, M., Quick, L. J., Verboom, G. A., and Reimer, P. J.: Extreme hydroclimate response gradients within the western Cape Floristic region of South Africa since the Last Glacial Maximum, Quaternary Sci. Rev., 219, 297-307, 2019.

Chase, B. M., Boom, A., Carr, A. S., Quick, L. J., and Reimer, P. J.: High-resolution record of Holocene climate change dynamics from southern Africa's temperate-tropical boundary, Baviaanskloof, South Africa, Palaeogeogr. Palaeocl., 539, 109518, https://doi.org/10.1016/j.palaeo.2019.109518, 2020.

Compton, J. S.: The mid-Holocene sea-level highstand at Bogenfels Pan on the southwest coast of Namibia, Quaternary Res., 66, 303-310, 2006.

Cooper, J. A. G., Green, A. N., and Compton, J. S.: Sea-level change in southern Africa since the Last Glacial Maximum, Quaternary Sci. Rev., 201, 303-318, 2018.

Damm, B. and Hagedorn, J.: Holocene floodplain formation in the southern Cape region, South Africa, Geomorphology, 122, 213222, 2010.

Diefendorf, A. F. and Freimuth, E. J.: Extracting the most from terrestrial plant-derived $n$-alkyl lipids and their carbon isotopes from the sedimentary record: A review, Org. Geochem., 103, 121, 2017. 
Douglas, P. M. J., Pagani, M., Eglinton, T. I., Brenner, M., Hodell, D. A., Curtis, J. H., Ma, K. F., and Breckenridge, A.: Pre-aged plant waxes in tropical lake sediments and their influence on the chronology of molecular paleoclimate proxy records, Geochim. Cosmochim. Ac., 141, 346-364, 2014.

Douglas, P. M. J., Pagani, M., Eglinton, T. I., Brenner, M., Curtis, J. H., Breckenridge, A., and Johnston, K.: A long-term decrease in the persistence of soil carbon caused by ancient Maya land use, Nat. Geosci., 11, 645-649, 2018.

du Plessis, N., Chase, B. M., Quick, L. J., Haberzettl, T., Kasper, T., and Meadows, M. E.: Vegetation and climate change during the Medieval Climate Anomaly and the Little Ice Age on the southern Cape coast of South Africa: Pollen evidence from Bo Langvlei, The Holocene, 30, 1716-1727, https://doi.org/10.1177/0959683620950444, 2020.

Duller, G. A. T.: Distinguishing quartz and feldspar in single grain luminescence measurements, Radiat. Meas., 37, 161-165, 2003.

Duller, G. A. T.: Assessing the error on equivalent dose estimates derived from single aliquot regenerative dose measurements, Ancient TL, 25, 15-24, 2007.

Duller, G. A. T.: Single-grain optical dating of Quaternary sediments: why aliquot size matters in luminescence dating, Boreas, 37, 589-612, 2008.

Eglinton, T. I. and Eglinton, G.: Molecular proxies for paleoclimatology, Earth Planet. Sc. Lett., 275, 1-16, 2008.

Engelbrecht, C. J. and Engelbrecht, F. A.: Shifts in Koppen-Geiger climate zones over southern Africa in relation to key global temperature goals, Theor. Appl. Climatol., 123, 247-261, 2016.

Engelbrecht, C. J. and Landman, W. A.: Interannual variability of seasonal rainfall over the Cape south coast of South Africa and synoptic type association, Clim. Dynam., 47, 295-313, 2016.

Engelbrecht, C. J., Landman, W. A., Engelbrecht, F. A., and Malherbe, J.: A synoptic decomposition of rainfall over the Cape south coast of South Africa, Clim. Dynam., 44, 2589-2607, 2015.

Engelbrecht, F. A., Landman, W. A., Engelbrecht, C. J., Landman, S., Bopape, M. M., Roux, B., McGregor, J. L., and Thatcher, M.: Multi-scale climate modelling over Southern Africa using a variable-resolution global model, Water Sa, 37, 647-658, 2011.

Feakins, S. J. and Sessions, A. L.: Crassulacean acid metabolism influences $\mathrm{D} / \mathrm{H}$ ratio of leaf wax in succulent plants, Org. Geochem., 41, 1269-1276, 2010.

Fey, M.: Soils of South Africa, Cambridge University Press, Cambridge, ISBN 9781107000506, 2010.

Fick, S. E. and Hijmans, R. J.: WorldClim 2: new 1-km spatial resolution climate surfaces for global land areas, Int. J. Climatol., 37, 4302-4315, 2017.

Frenzel, P.: Fossils of the southern Baltic Sea as palaeoenvironmental indicators in multi-proxy studies, Quatern. Int., 511, 6-21, 2019.

Fürstenberg, S., Gründler, N., Meschner, S., and Frenzel, P.: Microfossils in surface sediments of brackish waters on the west coast of South Africa and their palaeoecological implications, Afr. J. Aquat. Sci., 42, 329-339, 2017.

Galbraith, R. F., Roberts, R. G., Laslett, G. M., H., Y., and Olley, J. M.: Optical dating of single and multiple grains of quartz from Jinmium rock shelter, northern Australia: part I, Experimental design and statistical models, Archaeometry, 41, 339-364, 1999.
Gierga, M., Hajdas, I., van Raden, U. J., Gilli, A., Wacker, L., Sturm, M., Bernasconi, S. M., and Smittenberg, R. H.: Longstored soil carbon released by prehistoric land use: Evidence from compound-specific radiocarbon analysis on Soppensee lake sediments, Quaternary Sci. Rev., 144, 123-131, 2016.

Guérin, G., Mercier, N., and Adamiec, G.: Dose-rate conversion factors: update, Ancient TL, 29, 5-8, 2011.

Haas, M., Bliedtner, M., Borodynkin, I., Salazar, G., Szidat, S., Eglinton, T. I., and Zech, R.: Radiocarbon Dating of Leaf Waxes in the Loess-Paleosol Sequence Kurtak, Central Siberia, Radiocarbon, 59, 165-176, 2017.

Haas, M., Kaltenrieder, P., Ladd, S. N., Welte, C., Strasser, M., Eglinton, T. I., and Dubois, N.: Land-use evolution in the catchment of Lake Murten, Switzerland, Quaternary Sci. Rev., 230, 106154, https://doi.org/10.1016/j.quascirev.2019.106154, 2020.

Haberzettl, T., Baade, J., Compton, J., Daut, G., Dupont, L., Finch, J., Frenzel, P., Green, A., Hahn, A., Hebbeln, D., Helmschrot, J., Humphries, M., Kasper, T., Kirsten, K., Mäusbacher, R., Meadows, M., Meschner, S., Quick, L., Schefuß, E., Wündsch, M., and Zabel, M.: Paleoenvironmental investigations using a combination of terrestrial and marine sediments from South Africa - The RAIN (Regional Archives for Integrated iNvestigations) approach, Zbl. Geol. Pal., Heft 1, 55-73, 2014.

Haberzettl, T., Kirsten, K. L., Kasper, T., Franz, S., Reinwarth, B., Baade, J., Daut, G., Meadows, M. E., Su, Y., and Mäusbacher, R.: Using ${ }^{210} \mathrm{~Pb}$-data and paleomagnetic secular variations to date anthropogenic impact on a lake system in the Western Cape, South Africa, Quat. Geochronol., 51, 53-63, 2019.

Hahn, A., Schefuß, E., Andò, S., Cawthra, H. C., Frenzel, P., Kugel, M., Meschner, S., Mollenhauer, G., and Zabel, M.: Southern Hemisphere anticyclonic circulation drives oceanic and climatic conditions in late Holocene southernmost Africa, Clim. Past, 13, 649-665, https://doi.org/10.5194/cp-13-649-2017, 2017.

Hahn, A., Miller, C., Andó, S., Bouimetarhan, I., Cawthra, H. C., Garzanti, E., Green, A. N., Radeff, G., Schefuß, E., and Zabel, M.: The Provenance of Terrigenous Components in Marine Sediments Along the East Coast of Southern Africa, Geochem. Geophy. Geosy., 19, 1946-1962, 2018.

Harris, C., Burgers, C., Miller, J., and Rawoot, F.: O- and H-isotope record of Cape Town rainfall from 1996 to 2008, and its application to recharge studies of Table Mountain groundwater, South Africa, S. Afr. J. Geol., 113, 33-56, 2010.

Heaton, T. J., Köhler, P., Butzin, M., Bard, E., Reimer, R. W., Austin, W. E. N., Bronk Ramsey, C., Grootes, P. M., Hughen, K. A., Kromer, B., Reimer, P. J., Adkins, J., Burke, A., Cook, M. S., Olsen, J., and Skinner, L. C.: Marine 20 - the marine radiocarbon age calibration curve (0-55,000 cal BP), Radiocarbon, 62, 779-820, https://doi.org/10.1017/RDC.2020.68, 2020.

Herrmann, N., Boom, A., Carr, A. S., Chase, B. M., West, A. G., Zabel, M., and Schefuß, E.: Hydrogen isotope fractionation of leaf wax $n$-alkanes in southern African soils, Org. Geochem., 109, 1-13, 2017.

Hoefs, M. J. L., Rijpstra, W. I. C., and Sinninghe Damsté, J. S.: The influence of oxic degradation on the sedimentary biomarker record I: evidence from Madeira Abyssal Plain turbidites, Geochim. Cosmochim. Ac., 66, 2719-2735, 2002.

Hogg, A. G., Heaton, T. J., Hua, Q., Palmer, J. G., Turney, C. S. M., Southon, J., Bayliss, A., Blackwell, P. G., Boswijk, G., Bronk Ramsey, C., Pearson, C., Petchey, F., Reimer, P., 
Reimer, R., and Wacker, L.: SHCal20 Southern Hemisphere calibration, 0-55,000 years cal BP, Radiocarbon, 62, 759-778, https://doi.org/10.1017/RDC.2020.59, 2020.

Hou, J., D’Andrea, W. J., MacDonald, D., and Huang, Y.: Evidence for water use efficiency as an important factor in determining the $\delta \mathrm{D}$ values of tree leaf waxes, Org. Geochem., 38, 1251-1255, 2007.

Jarvis, A., Reuter, H. I., Nelson, A. and Guevara, E.: Holefilled SRTM for the globe Version 4, CGIARCSI SRTM 90m Database, available at: http://srtm.csi.cgiar.org (last access: 8 February 2021), 2008.

Johnson, M. R., Anhausser, C. R., and Thomas, R. J.: The geology of South Africa, Geological Society of South Africa, Johannesburg/Council for Geoscience, Pretoria, 2006.

Kirsten, K. L., Fell, J., Frenzel, P., Meschner, S., Kasper, T., Wündsch, M., Meadows, M., and Haberzettl, T.: The spatial heterogeneity of micro- and meio-organisms and their significance in understanding coastal system dynamics, Estuar. Coast. Shelf S., 213, 98-107, 2018a.

Kirsten, K. L., Haberzettl, T., Wündsch, M., Frenzel, P., Meschner, S., Smit, A. J., Quick, L. J., Mäusbacher, R., and Meadows, M. E.: A multiproxy study of the ocean-atmospheric forcing and the impact of sea-level changes on the southern Cape coast, South Africa during the Holocene, Palaeogeogr. Palaeocl., 496, 282291, 2018 b.

Kirsten, K. L., Kasper, T., Cawthra, H. C., Strobel, P., Quick, L. J., Meadows, M. E., and Haberzettl, T.: Holocene variability in climate and oceanic conditions in the winter rainfall zone of South Africa - inferred from a high resolution diatom record from Verlorenvlei, J. Quaternary Sci., 35, 572-581, 2020.

Ladd, S. N. and Sachs, J. P.: Inverse relationship between salinity and $n$-alkane $\delta \mathrm{D}$ values in the mangrove Avicennia marina, Org. Geochem., 48, 25-36, 2012.

Marker, M. E. and Miller, D. E.: A mid-Holocene high stand of the sea at Knysna, S. Afr. J. Sci., 89, 100-102, 1993.

Martens, K., Davies, B. R., Baxter, A. J., and Meadows, M. E.: A contribution to the taxonomy and ecology of the Ostracoda (Crustacea) from Verlorenvlei (Western Cape, South Africa), Afr. Zool., 31, 22-36, 1996.

Martin, A. R. H.: The stratigraphy and history of Groenvlei, a South African coastal fen, Aust. J. Bot., 7, 142-167, 1959.

Martin, A. R. H.: Pollen Analysis of Groenvlei Lake Sediments Knysna (South Africa), Rev. Palaeobot. Palyno., 7, 107-144, 1968.

Meisch, C.: Crustacea: Ostracoda, in: Süßwasserfauna von Mitteleuropa, edited by: Schwoerbel, J. and Zwick, P., Spektrum Akademischer Verlag, Heidelberg, Berlin, ISBN: 978$3827410016,2000$.

Mejdahl, V.: Thermoluminescence dating: Beta-dose attenuation in quartz grains, Archaeometry, 21, 61-72, 1979.

Mucina, L. and Rutherford, M. C.: The vegetation of South Africa, Lesotho and Swaziland, SANBI, Pretoria, ISBN: 9781919976211, 2006.

Murray, A. S. and Wintle, A. G.: Luminescence dating of quartz using an improved single-aliquot regenerative-dose protocol, Rad. Meas., 32, 57-73, 2000.

Murray, A. S. and Wintle, A. G.: The single aliquot regenerative dose protocol: potential for improvements in reliability, Radiat. Meas., 37, 377-381, 2003.
Murray, J. W.: Ecology and applications of benthic foraminifera, Cambridge University Press, Cambridge, ISBN: 9780511535529, 2006.

Ohlendorf, C. and Sturm, M.: A modified method for biogenic silica determination, J. Paleolimnol., 39, 137-142, 2008.

Olsen, J., Kjær, K. H., Funder, S., Larsen, N. K., and Ludikova, A.: High-Arctic climate conditions for the last 7000 years inferred from multi-proxy analysis of the Bliss Lake record, North Greenland, J. Quaternary Sci., 27, 318-327, 2012.

Pecharsky, V. K. and Zavalij, P. Y.: Fundamentals of Powder Diffraction and Structural Characterization of Materials, Springer, Boston, ISBN: 9780387095783, 2009.

Poynter, J. G., Farrimond, P., Robinson, N., and Eglinton, G.: Aeolian-Derived Higher Plant Lipids in the Marine Sedimentary Record: Links with Palaeoclimate, in: Paleoclimatology and Paleometeorology: Modern and Past Patterns of Global Atmospheric Transport, edited by: Leinen, M. and Sarnthein, M., Springer Netherlands, Dordrecht, 435-462, 1989.

Preusser, F., Degering, D., Fuchs, M., Hilgers, A., Kadereit, A., Klasen, N., Krbetschek, M., Richter, D., and Spencer, J. Q. G.: Luminescence dating: basics, methods and applications, E\&G Quaternary Sci. J., 57, 95-149, https://doi.org/10.3285/eg.57.12.5, 2008.

Prescott, J. R. and Hutton, J. T.: Cosmic ray contributions to dose rates for luminescence and ESR dating: Large depths and longterm time variations, Radiat. Meas., 23, 497-500, 1994.

Quick, L. J., Meadows, M. E., Bateman, M. D., Kirsten, K. L., Mäusbacher, R., Haberzettl, T., and Chase, B. M.: Vegetation and climate dynamics during the last glacial period in the fynbos-afrotemperate forest ecotone, southern Cape, South Africa, Quatern. Int., 404, 136-149, 2016.

Quick, L. J., Chase, B. M., Wündsch, M., Kirsten, K., Chevalier, M., Mäusbacher, R., Meadows, M., and Haberzettl, T.: A highresolution record of Holocene climate and vegetation dynamics from the southern Cape coast of South Africa: pollen and microcharcoal evidence from Eilandvlei, J. Quaternary Sci., 33, 487-500, 2018.

Rautenbach, C., Barnes, M. A., and de Vos, M.: Tidal characteristics of South Africa, Deep-Sea Res. Pt. I, 150, 103079 , https://doi.org/10.1016/j.dsr.2019.103079, 2019.

Reddering, J. S. V.: Evidence for a middle Holocene transgression, Keurbooms estuary, South Africa, Palaeoecol. Afr., 19, 79-86, 1988.

Reinwarth, B., Franz, S., Baade, J., Haberzettl, T., Kasper, T., Daut, G., Helmschrot, J., Kirsten, K. L., Quick, L. J., Meadows, M. E., and Mäusbacher, R.: A 700-Year Record on the Effects of Climate and Human Impact on the Southern Cape Coast Inferred from Lake Sediments of Eilandvlei, Wilderness Embayment, South Africa, Geogr. Ann. A, 95, 345-360, 2013.

Ruff, M., Fahrni, S., Gäggeler, H. W., Hajdas, I., Suter, M., Synal, H. A., Szidat, S., and Wacker, L.: On-line Radiocarbon Measurements of Small Samples Using Elemental Analyzer and MICADAS Gas Ion Source, Radiocarbon, 52, 1645-1656, 2010.

Sachse, D., Billault, I., Bowen, G. J., Chikaraishi, Y., Dawson, T. E., Feakins, S. J., Freeman, K. H., Magill, C. R., McInerney, F. A., van der Meer, M. T. J., Polissar, P., Robins, R. J., Sachs, J. P., Schmidt, H. L., Sessions, A. L., White, J. W. C., West, J. B., and Kahmen, A.: Molecular Paleohydrology: Interpreting the Hydrogen-Isotopic Composition of Lipid Biomarkers from Pho- 
tosynthesizing Organisms, Annu. Rev. Earth Pl. Sc., 40, 221249, 2012.

Salazar, G., Zhang, Y. L., Agrios, K., and Szidat, S.: Development of a method for fast and automatic radiocarbon measurement of aerosol samples by online coupling of an elemental analyzer with a MICADAS AMS, Nucl. Instrum. Meth. B, 361, 163-167, 2015.

Schmitt-Sinns, J.: Rezente benthische Foraminiferen im Bereich des Benguelastroms, Südwestafrika Verbreitungsmuster und ihre steuernden Faktoren, PhD thesis, University of Bonn, Germany 2008.

Scott, L. and Lee-Thorp, J. A.: Holocene climatic trends and rhythms in southern Africa, in: Past Climate Variability through Europe and Africa, edited by: Battarbee, R. W., Gasse, F., and Stickley, C. E., Springer, Dordrecht, ISBN: 978-90-481-6593-3, 2004.

Sessions, A. L.: Factors controlling the deuterium contents of sedimentary hydrocarbons, Org. Geochem., 96, 43-64, 2016.

Song, Y. and Müller, G.: Freshwater sediments: Sinks and sources of bromine, Naturwissenschaften, 80, 558-560, 1993.

Strachan, K. L., Hill, T. R., Finch, J. M., Barnett, R. L., and Frenzel, P.: Distribution of Salt-Marsh Foraminifera in Two South African Estuaries and the Application as Sea-Level Indicators, J. Coastal Res., 33, 619-631, 2017.

Strobel, P., Kasper, T., Frenzel, P., Schittek, K., Quick, L. J., Meadows, M. E., Mäusbacher, R., and Haberzettl, T.: Late Quaternary palaeoenvironmental change in the year-round rainfall zone of South Africa derived from peat sediments from Vankervelsvlei, Quaternary Sci. Rev., 218, 200-214, 2019.

Strobel, P., Haberzettl, T., Bliedtner, M., Struck, J., Glaser, B., Zech, M., and Zech, R.: The potential of $\delta^{2} \mathrm{H}_{n_{\text {-alkanes }}}$ and $\delta^{18} \mathrm{O}_{\text {sugar }}$ for paleoclimate reconstruction - A regional calibration study for South Africa, Sci. Total Environ., 716, 137045, https://doi.org/10.1016/j.scitotenv.2020.137045, 2020.

Struck, J., Bliedtner, M., Strobel, P., Schumacher, J., Bazarradnaa, E., and Zech, R.: Leaf wax $n$-alkane patterns and compoundspecific $\delta^{13} \mathrm{C}$ of plants and topsoils from semi-arid and arid Mongolia, Biogeosciences, 17, 567-580, https://doi.org/10.5194/bg17-567-2020, 2020.

Stuiver, M., Reimer, P. J., and Reimer, R. W.: CALIB 8.2 [WWW program], available at: http://calib.org/, last access: 20 August 2020.

Szidat, S., Salazar, G. A., Vogel, E., Battaglia, M., Wacker, L., Synal, H.-A., and Türler, A.: 14C Analysis and Sample Preparation at the New Bern Laboratory for the Analysis of Radiocarbon with AMS (LARA), Radiocarbon, 56, 561-566, 2014.

Talma, A. S. and Vogel, J. C.: Late Quaternary paleotemperatures derived from a speleothem from Cango Caves, Cape Province, South Africa, Quaternary Res., 37, 203-213, 1992.
Tyson, P. D. and Preston-Whyte, R. A.: The Weather and Climate of Southern Africa, Oxford University Press, Cape Town, ISBN: 9780195718065, 2000.

Ullman, W. J.: The fate and accumulation of bromide during playa salt deposition: An example from Lake Frome, South Australia, Geochim. Cosmochim. Ac., 59, 2175-2186, 1995.

Walters, W. L. and Griffiths, C. L.: Patterns of distribution, abundance and shell utilization amongst hermit crabs, Diogenes brevirostris, S. Afr. J. Zool., 22, 269-277, 1987.

Weldon, D. and Reason, C. J. C.: Variability of rainfall characteristics over the South Coast region of South Africa, Theor. Appl. Climatol., 115, 177-185, 2014.

Weltje, G. J. and Tjallingii, R.: Calibration of XRF core scanners for quantitative geochemical logging of sediment cores: Theory and application, Earth Planet. Sc. Lett., 274, 423-438, 2008.

Wintle, A. G.: Luminescence dating: laboratory procedures and protocols, Rad. Meas., 27, 769-817, 1997.

Wintle, A. G. and Murray, A. S.: A review of quartz optically stimulated luminescence characteristics and their relevance in singlealiquot regeneration dating protocols, Rad. Meas., 41, 369-391, 2006.

Wündsch, M., Haberzettl, T., Kirsten, K. L., Kasper, T., Zabel, M., Dietze, E., Baade, J., Daut, G., Meschner, S., Meadows, M. E., and Mäusbacher, R.: Sea level and climate change at the southern Cape coast, South Africa, during the past $4.2 \mathrm{kyr}$, Palaeogeogr. Palaeocl., 446, 295-307, 2016a.

Wündsch, M., Haberzettl, T., Meadows, M. E., Kirsten, K. L., Kasper, T., Baade, J., Daut, G., Stoner, J. S., and Mäusbacher, R.: The impact of changing reservoir effects on the C-14 chronology of a Holocene sediment record from South Africa, Quat. Geochronol., 36, 148-160, 2016b.

Wündsch, M., Haberzettl, T., Cawthra, H. C., Kirsten, K. L., Quick, L. J., Zabel, M., Frenzel, P., Hahn, A., Baade, J., Daut, G., Kasper, T., Meadows, M. E., and Mäusbacher, R.: Holocene environmental change along the southern Cape coast of South Africa - Insights from the Eilandvlei sediment record spanning the last 8.9 kyr, Global Planet. Change, 163, 51-66, 2018.

Zech, M., Buggle, B., Leiber, K., Marković, S., Glaser, B., Hambach, U., Huwe, B., Stevens, T., Sümegi, P., Wiesenberg, G., and Zöller, L.: Reconstructing Quaternary vegetation history in the Carpathian Basin, SE-Europe, using $n$-alkane biomarkers as molecular fossils: Problems and possible solutions, potential and limitations, E\&G Quaternary Sci. J., 58, 148-155, https://doi.org/10.3285/eg.58.2.03, 2010.

Zech, W., Schad, P., and Hintermaier-Erhard, G.: Böden der Welt: Ein Bildatlas, EBL-Schweitzer, Berlin; Heidelberg, ISBN: 9783642365744, 2014. 